\title{
$P-T$ evolution of eclogites from the Agualada Unit (Ordenes Complex, northwest Iberian Massif, Spain): Implications for crustal subduction
}

\author{
R. Arenas ${ }^{\text {a, * }}$, J. Abati ${ }^{\text {a }}$, J.R. Martínez Catalán ${ }^{\text {b }}$, F. Díaz García ${ }^{\text {c }}$, \\ F.J. Rubio Pascual ${ }^{\text {a }}$ \\ a Departamento de Petrología y Geoquímica, Facultad de Geología, Universidad Complutense, 28040 Madrid, Spain \\ bepartamento de Geología, Universidad de Salamanca, 37008 Salamanca, Spain \\ c Departamento de Geología, Universidad de Oviedo, 33005 Oviedo, Spain
}

\begin{abstract}
Eclogite lenses in the Agualada Unit (western Ordenes Complex, Spain) contain the peak mineral assemblage garnet (prograde rim: $\mathrm{Alm}=48 \mathrm{~mol} \%$, Prp $=30 \mathrm{~mol} \%$ ), omphacite ( $\mathrm{Jd} \max =36 \mathrm{~mol} \%$ ), quartz, rutile and rare zoisite, which equilibrated at $T=700^{\circ} \mathrm{C}$ and $P>12-14 \mathrm{kbar}$. Garnet shows discontinuous growth zoning, with a pyrope-poor intermediate zone $(\mathrm{Alm}=51 \mathrm{~mol} \%, \operatorname{Prp}=10 \mathrm{~mol} \%)$ between a core zone where pyrope is slightly higher $(\mathrm{Alm}=46 \mathrm{~mol} \%, \operatorname{Prp}=16$ $\mathrm{mol} \%$ ) and areas just inward from the rims where the maximum pyrope contents (Alm $=48 \mathrm{~mol} \%, \operatorname{Prp}=30 \mathrm{~mol} \%$ ) are reconded. In atoll interiors, garnet contains inclusions of a first generation of omphacite (Jd $\max =40 \mathrm{~mol} \%$ ). This omphacite is replaced in the matrix by a second generation ( $\mathrm{Jd} \max =36 \mathrm{~mol} \%$ ) with higher $\mathrm{Fe} / \mathrm{Fe}+\mathrm{Mg}$ ratio. The compositions of garnet and omphacite suggest a complex syneclogitic tectonothermal evolution for the Agualada Unit, characterized by: (1) eclogite-facies metamorphism $\left(T=585^{\circ} \mathrm{C}, P>12-13 \mathrm{kbar}\right)$, followed by (2) cooling during a slight decompression ( $T=500^{\circ} \mathrm{C}, P>11-12 \mathrm{kbar}$ ), and (3) a final increase in $P$ and $T$ to form the garnet rim-matrix omphacite mineral assemblage. The Agualada Unit is part of a subduction complex which affected the Gondwana margin at the beginning of the Variscan cycle. The $P-T$ evolution of the Agualada eclogites is closely related to the structural evolution of the accretionary complex and the whole orogenic wedge. The cooling event recorded by the Agualada eclogites may have resulted from the accretion of a new colder crustal slice under the unit, whereas the final progradation reflects the emplacement of the Agualada Unit directly under the mantle wedge. This evolution fits well with previously presented theoretical models, both for the tectonothermal evolution of accretionary complexes and for the dynamic evolution of orogenic wedges. $P-T$ paths such as the one for the Agualada Unit eclogites, probably reflect a prolonged structural evolution. Although evidently rarely preserved, such paths are probably the rule rather than the exception during plate convergence.
\end{abstract}

Keywords: Eclogites; P-T path; Continental subduction

• Corresponding author. Tel.: + 34-1-3944908; fax: 34-1-5442535; e-mail: arenas@eucmax.sim.ucm.es. 


\section{Introduction}

The initial evolution of orogenic belts generally involves the subduction of continental slabs to great depths, as is documented in Alpine collisional belts (Ernst, 1971; Mattauer, 1983; Chopin, 1984; Platt. 1986) and in older orogens (Austrheim and Griffin, 1985; Matte et al., 1993; Arenas et al., 1995; Martínez Catalán et al., 1996). The preservation of lithologies with high- $P$ metamorphic parageneses in these orogenic terranes and especially the exhumation mechanism of these lithologies, has been the subject of much research (Platt, 1986, 1987). Some models usually propose a shortening of the descending slab during subduction, because of the density contrast between this slab and the lower crust or the mantle wedge. This shortening has to be accommodated by folding and/or imbrication of the subducted materials. Relationships between these tectonic mechanisms and metamorphic processes are modeled by solving the heat flow equation to obtain theoretical $P, T, t$ paths (Oxburgh and Turcotte, 1974; England and Thompson, 1984; Royden and Hodges, 1984: Davy and Gillet, 1986; Peacock, 1990; Peacock et al., 1994). However, determination of the actual $P$, $T, t$ paths followed by a high- $P$ metamorphic rock is somewhat more difficult, as the high- $P$ metamorphism is developed at the beginning of the orogenic cycle and its mineral assemblages are in general strongly overprinted by subsequent tectonothermal events.

This article describes the characteristics and geodynamic implications of the tectonothermal evolution of some eclogites from a subducted slab. The most outstanding characteristic of these rocks is the preservation of prepeak mineral assemblages as micro-inclusions in the eclogite-facies minerals. The micro-inclusions and the garnet compositional zoning are combined to obtain a syneclogite facies $P-T$ path we attribute to the imbrication of two subducted units.

\section{Geological setting}

The Agualada Unit is located at the base of the northwestern part of the Ordenes Complex. The Ordenes Complex is a large allochthonous klippe in the northwestern Iberian Massif (Fig. 1). In this region, a complete transition occurs from the external zones to the innermost part of the European Variscan Belt. These structures have been named Allochthonous Complexes because they consist of several tectonostratigraphic units, which can be differentiated both by their lithologies and different metamorphic evolution, and because they are tectonically emplaced over a parautochthonous metasedimentary sequence (for further details see Martínez Catalán et al., 1984; Arenas et al., 1986; Gil Ibarguchi and Arenas, 1990; Martínez Catalán, 1990). The Allochthonous Complexes consist of three main tectonostratigraphic ensembles, which from bottom to top are the basal, ophiolitic and uppermost units (Figs. 1 and 2).

The basal units consist of continental rocks, which include monotonous pelitic and semi-pelitic schists and paragneisses, granitic orthogneisses and scattered intercalations of metabasites. Radiometric ages obtained in the orthogneiss bodies range between 450-470 Ma ( $\mathrm{Rb} / \mathrm{Sr}$, whole rock; van Calsteren et al., 1979; García Garzón et al., 1981) and $480 \mathrm{Ma}$ (U-Pb in zircons; Santos Zalduegui et al., 1995), and are interpreted as igneous ages of the granitic protoliths. The metabasites include amphibolite layers ranging in thickness from decimeters to a few meters, and small bodies of variably retrogressed eclogite, generally included in the orthogneisses. The basal units show evidence of having had an early high- $P$ and generally low to intermediate- $T$ metamorphism. Eclogites and blueschists were developed from basic protoliths (Van der Wegen, 1978; Gil Ibarguchi and Ortega Gironés, 1985). High- $P$, low to intermediate- $T$ parageneses are preserved as $\mathrm{Si}$ inclusions in albitic porphyroblasts in semi-pelitic schists (Arenas et al., 1995) and mineral assemblages with pure jadeite are found in quartz-feldspathic rocks (Gil Ibarguchi, 1995). In many areas, the high- $P$ parageneses are intensely overprinted by mineral assemblages that equilibrated at intermediate- $P$. In highly deformed zones, no relics of this initial event are preserved. The age of the high- $P$ episode is estimated as eo-Hercynian, as suggested by different $\mathrm{Rb} / \mathrm{Sr}$ ages ranging between $352-370$ Ma obtained for eclogites, eclogitic schists and metagranodiorites of the Malpica-Tuy Unit, and generally interpreted as cooling ages close to the end of the high- $P$ episode (van Calsteren et al., 1979; San- 
tos Zalduegui et al., 1995). Because the basal units crop out under the Variscan suture, which is marked by the position of the overlying ophiolitic units, and they show early high $P / T$ metamorphism, they are interpreted as part of the Gondwana margin subducted during convergence with an exotic terrane, represented by the uppermost units (Arenas et al., 1986; Marínez Catalán, 1990; Arenas et al., 1995).

From bottom to top, the lithologies of the Agualada Unit are: (1) a very narrow discontinuous band of highly serpentinized ultramafic rocks and amphibolites associated with the contact of the underlying Santiago Unit; (2) migmatitic paragneisses with amphibolite intercalations; and (3) granitic orthogneisses which contain lenticular bodies of eclogite in different stages of retrogression (Fig. 2). During high- $P$ metamorphism, the migmatitic paragneisses recrystallized to an assemblage of garnet, plagioclase, quartz, kyanite, biotite ( \pm muscovite) and rutile. During post-eclogite facies decompression of the unit, the paragneisses partially melted to form leucocratic regions that consist of quartz, plagioclase, kyanite and minor biotite. The orthogneisses show blastomylonitic textures, contain significant amounts of $\mathrm{K}$-feldspar, and lack aluminium silicate minerals. Some of the amphibolites are rich in gamet and clinopyroxenes.

The structure of the Agualada Unit is homoclinal, dipping approximately $45^{\circ} \mathrm{E}$. It overlies the Santiago Unit and underlies ophiolitic rocks of the Ordenes Complex. This upper contact is interpreted as an extensional fault because of an apparent discontinuity in pressure between the Agualada Unit and the ophiolitic rocks (Fig. 2). The minimum $P$ estimated for the Agualada Unit is $14 \mathrm{kbar}$ (as will be discussed below), but estimated pressures for the ophiolitic rocks did not exceed 9 kbar (Díaz García, 1990).

The Ophiolitic Units of the Ordenes Complex represent the Variscan suture in the northwest Iberian

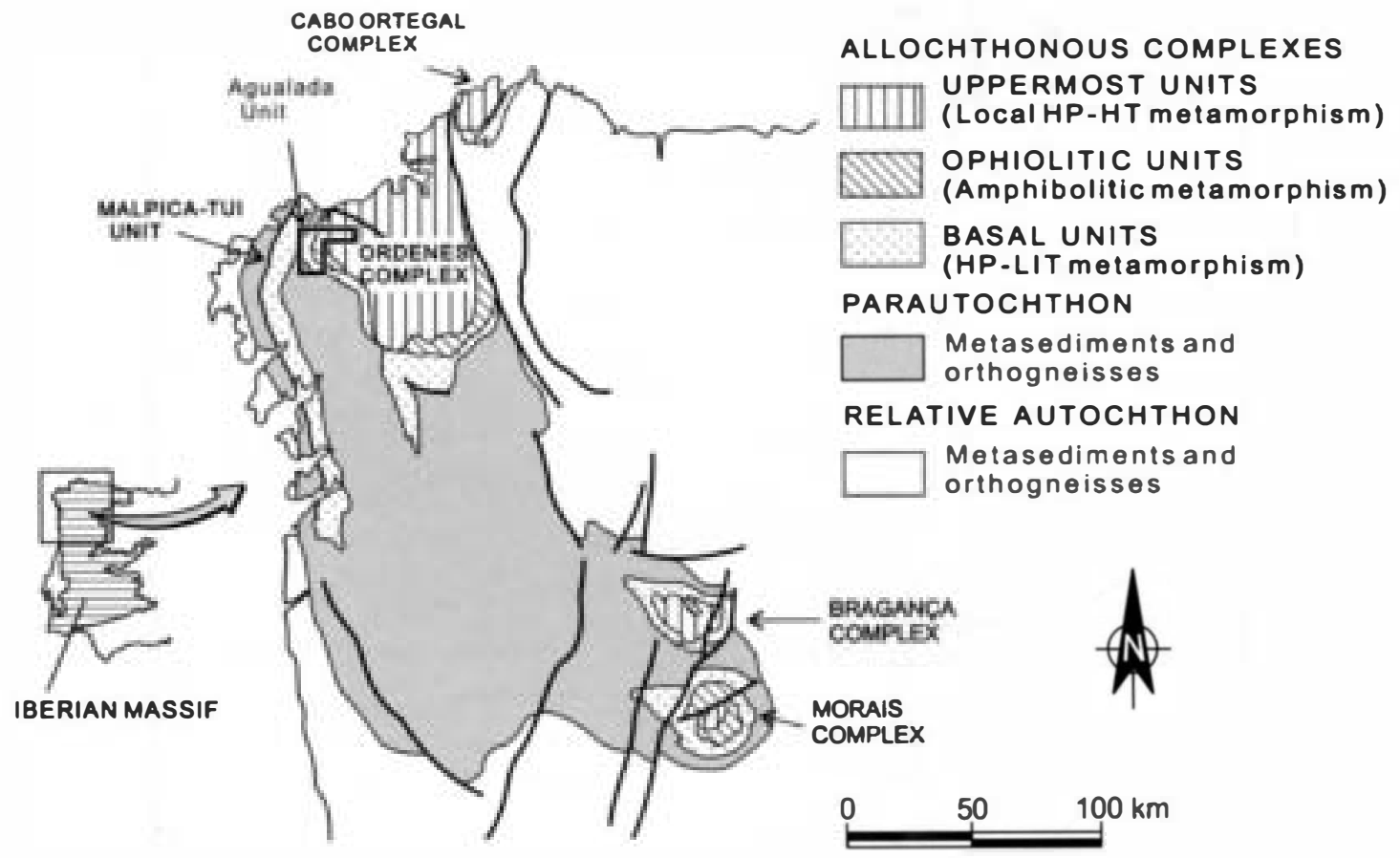

Fig. 1. Geological sketch of the northwest Iberian Massif, showing the five allochthonous structures which constitute the domain of the complexes and the tectonostratigraphic units in which they are divided (Arenas et al., 1995; Martínez Catalán et al., 1996). In the western Ordenes Complex two superposed basal units cropout; they receive the local names of Santiago Unit and Agualada Unit. The box encloses the Agualada Unit and corresponds to the area enlarged in Fig. 2. 
Massif (Arenas et al., 1995; Martínez Catalán et al., 1996). They consist of amphibolites, metagabbros and ultramafic rocks which are generally highly serpentinized. Although their metamorphism reflects amphibolite-facies conditions, locally it may reach the intermediate- $P$ part of the granulite facies (Díaz García, 1990). ${ }^{40} \mathrm{Ar} /{ }^{39} \mathrm{Ar}$ hornblende ages of rocks from Cabo Ortegal, Bragança and Morais Com- plexes, range between 384-392 Ma (Dallmeyer and Gil Ibarguchi, 1990; Peucat et al., 1990; Dallmeyer et al., 1991), and are interpreted as the age of accretion of the ophiolite beneath the overlying unit.

The uppermost units are interpreted as a composite, far-travelled terrane (Arenas et al., 1986). They consist of thick sections of metasedimentary rocks, orthogneisses, metabasites and ultramafic rocks

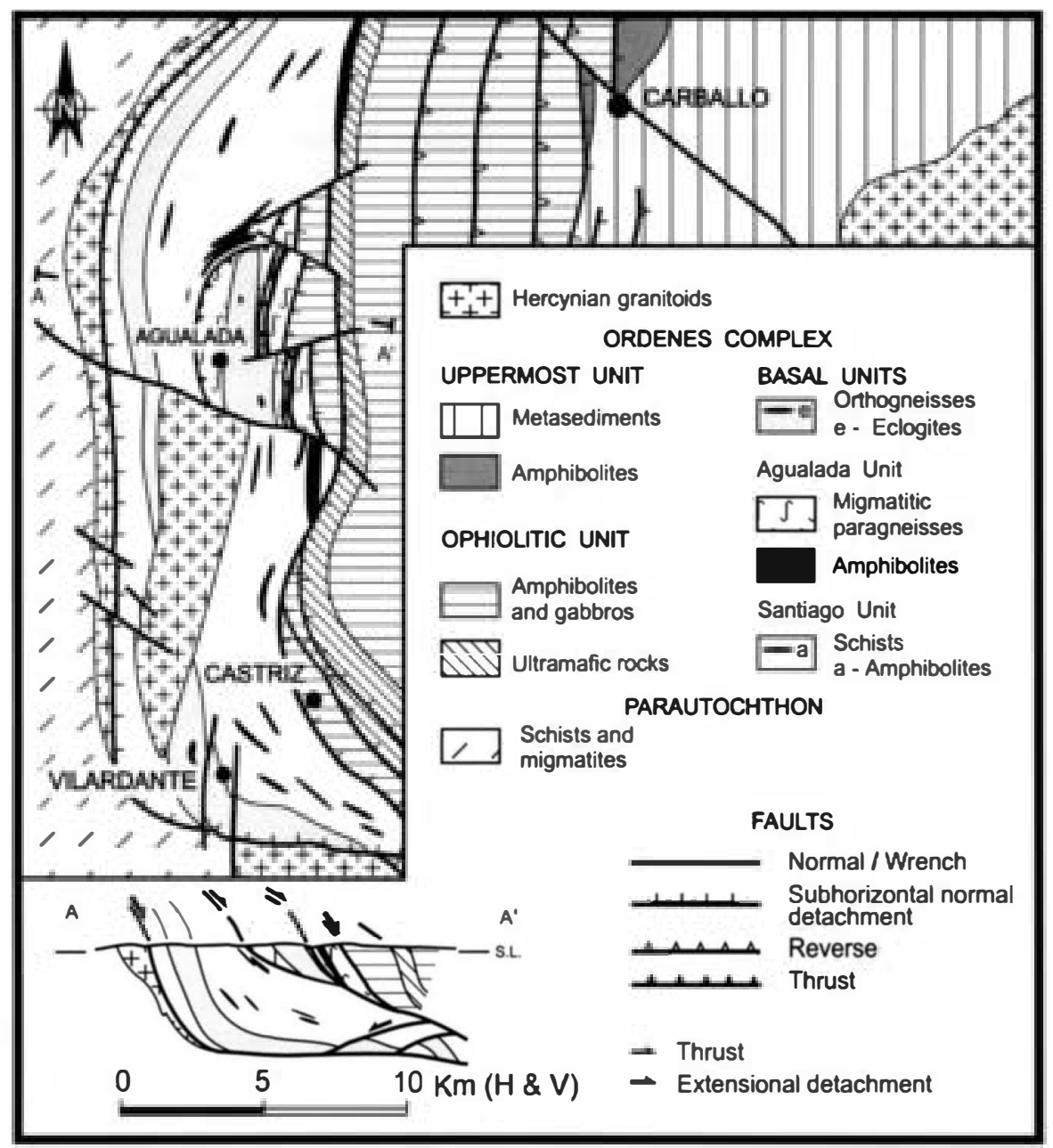

Fig. 2. Simplified geological map and cross-section of the northwestern Ordenes Complex (modified from Díaz García, 1990). 
(Martínez Catalán et al., 1984). Some were affected by high- $P$, high- $T$ metamorphism that was dated at ca. 390-400 Ma using U/Pb-SHRIMP methods (Schäfer et al., 1993). Other sectors display a prograde metamorphism of greenschist to amphibolite facies. Some post-high- $P$ events are of extensional character (Martínez Catalán and Arenas, 1992; Arenas and Martínez Catalán, 1993). Both emplacement of the ophiolitic units and the high- $P$ metamorphism of the basal units are probably related to convergence and collision of the Gondwana margin and the composite terrane represented by the Uppermost Units. This collision has recently been described by Martínez Catalán et al. (1996) and resembles the model proposed by Platt (1986) for the dynamic evolution of orogenic wedges.

\section{Field relationships of the eclogitic bodies}

The regional fabric in the Agualada Unit is a gneissic foliation; in part it reflects deformation under amphibolite facies conditions but continued during greenschist facies metamorphism (Abati, 1994). Well-preserved eclogitic masses occur as isolated bodies within the orthogneisses of the Agualada Unit. They are found as centimeter to meter sized boudins, black or dark green in color, intensely amphibolitized on their outer margins. They are derived from dikes or basic sills that were emplaced prior to Variscan deformation, probably during bimodal magmatism connected also with genesis of the orthogneisses of the basal units (Gil Ibarguchi and Ortega Gironés, 1985). Leucosomatic regions that consist of quartz, plagioclase and centimeter-sized grains of kyanite are typically observed along boudin margins, particularly in necked regions. The cores of the boudins preserve fine-grained granoblastic to grano-nematoblastic eclogites. In the latter, a syneclogitic foliation $\left(S_{1}\right)$ is defined by the orientation of omphacite and rutile grains. Where deformation is more intense, the regional external schistosity seen in the gneisses also affects the eclogite boudins, producing amphibolitization. This observation suggests that the regional schistosity of the Agualada Unit is linked to decompression.

\section{Petrography of the eclogites}

The eclogites of the Agualada Unit are finegrained, and contain omphacite + garnet + quartz + rutile \pm zoisite. Textures vary from grano-nematoblastic to isotropic. Grano-nematoblastic types display a planar fabric defined by the orientation of omphacites, rutiles and many idiomorphic garnet porphyroblasts (Fig. 3a and b). In contrast, isotropic eclogite samples show a honeycomb-like texture that arises from coalescence of numerous atoll garnets (Fig. 3c and d). Nonatoll garnets $(0.25-1 \mathrm{~mm}$ in diameter) are clear, with a few inclusions of clinopyroxenes, quartz, and rutile in their cores. The atoll garnets $(0.3-2 \mathrm{~mm}$ in diameter across the filled core) are generally idiomorphic, in both their outer and inner rims. In less retrogressed eclogites, these garnets contain inclusions of a first generation of clinopyroxene. In retrogressed samples, this clinopyroxene reacts with garnet to form secondary clinopyroxene, hornblende, plagioclase and quartz. Honeycomb-like textures are interpreted in two ways: (1) prograde growth of garnet at the expense of pre-existing minerals, by means of segregation from reaction coronas (Lasnier, 1977), or by nucleation and growth from triple junctions (Wit and Strong, 1975); (2) partial replacement of garnet cores by retrograde reactions that leave a neoblastic aggregate in the interior (Rast, 1965). In other eclogites of the basal units, honeycomb-like texture has been interpreted to reflect the latter (Van der Wegen, 1978; Gil Ibarguchi and Ortega Gironés, 1985). However, in the eclogites of the Agualada Unit this texture appears to have originated from the former mechanism, for two reasons. First, both the outer and inner rims of atoll garnets are idiomorphic. Second, the clinopyroxene inclusions in the such garnets are not a product of their retrogression.

In summary, two generations of eclogitic clinopyroxenes have been differentiated in the Agualada eclogites: (1) type I clinopyroxene $(0.2-0.9 \mathrm{~mm}$ in diameter) which is included in atoll and idiomorphic garnets (Fig. 3E) and (2) type II clinopyroxene (generally $<1 \mathrm{~mm}$ ), which are elongated tabular crystals that define the matrix foliation of the eclogite (Fig. $3 a$ and $b$ ).

Amphibolite-facies retrogression initially developed a clinopyroxene-plagioclase symplectite in the 


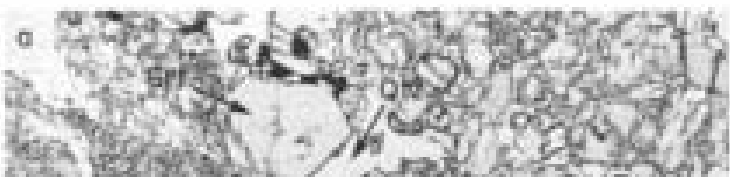

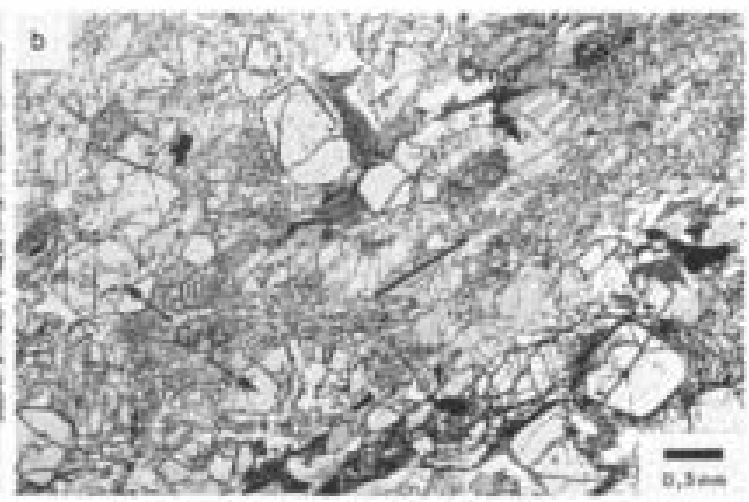
If

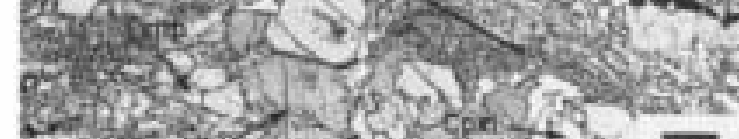

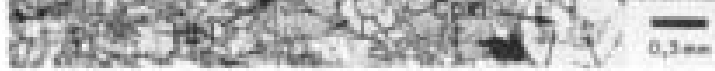
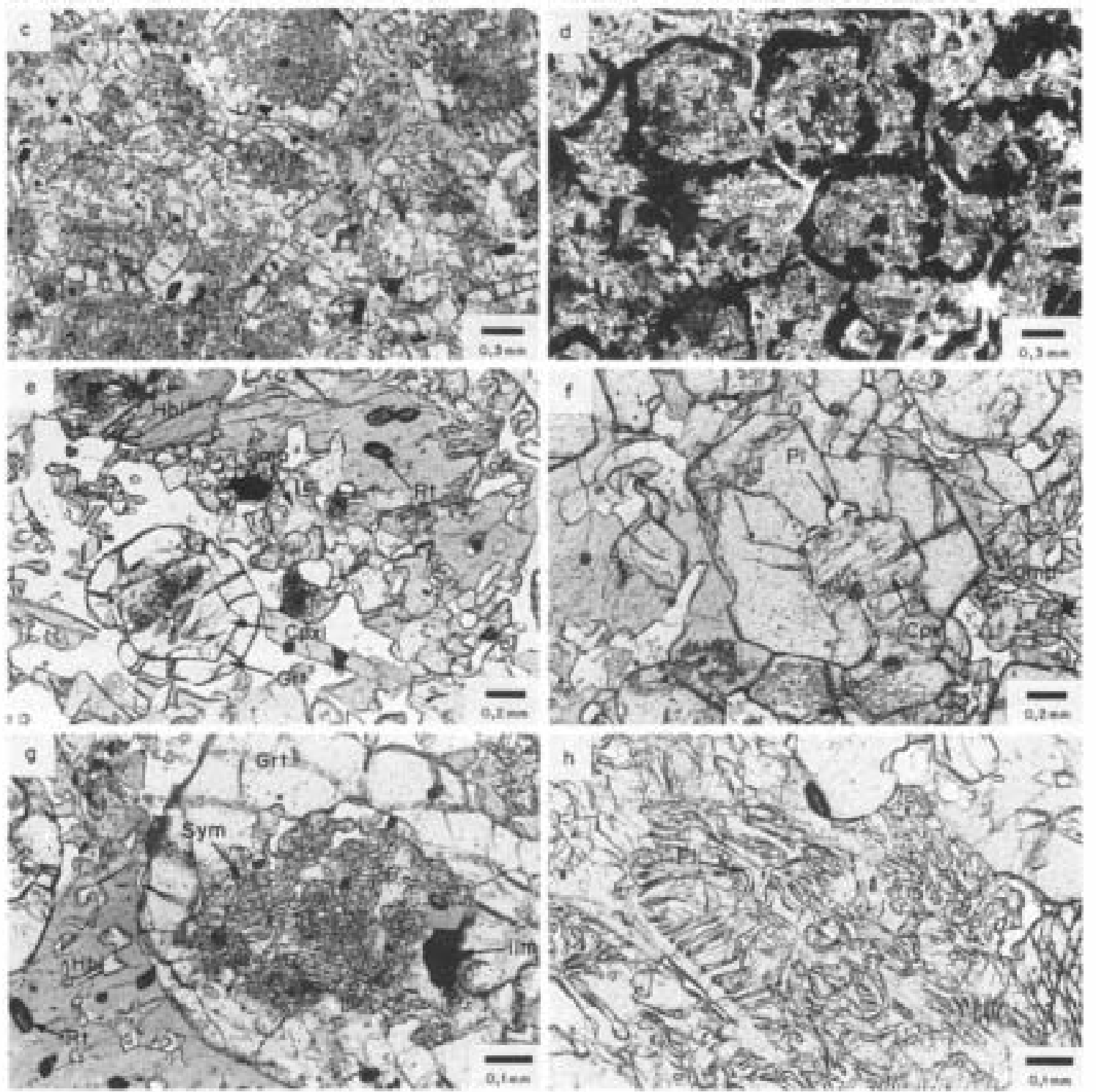


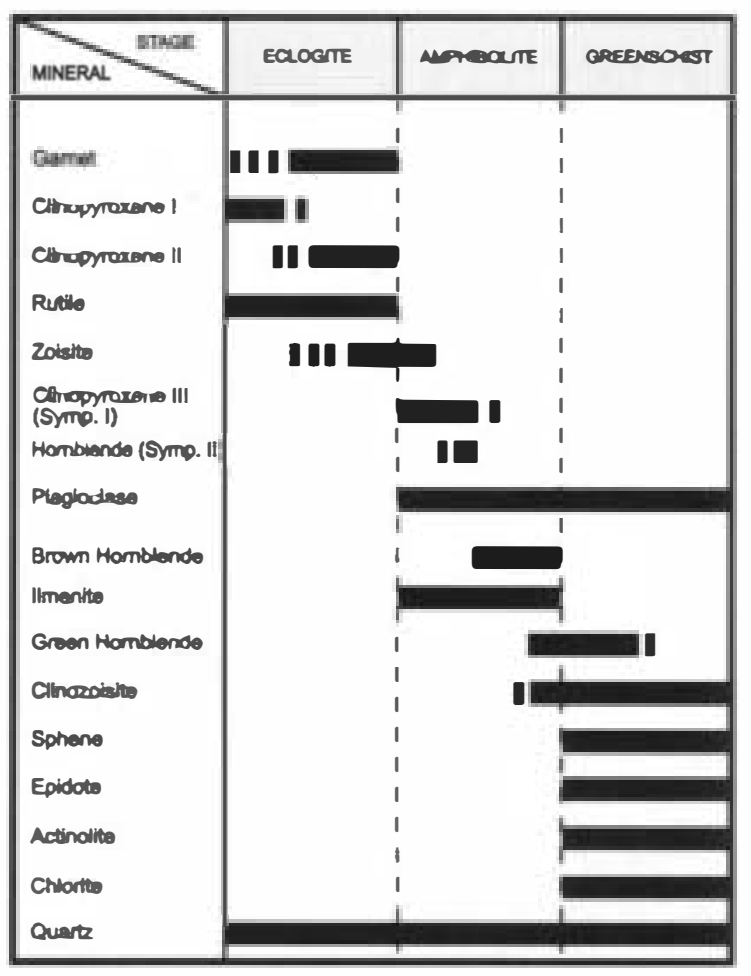

Fig. 4. Mineral assemblages of Agualada Unit eclogites.

eclogitic clinopyroxene (Fig. 3h; symplectite I), and a more-or-less simultaneous growth of tabular clinopyroxenes, darker in color than clinopyroxene I or III; all these secondary clinopyroxenes will be designated as type III clinopyroxene. Symplectite I consists of relatively coarse grains, which suggest it crystallized at relatively high temperature (Vogel, 1967). These are replaced by symplectite II consisting of clinopyroxene III + plagioclase \pm homblende. Textures of plagioclase and homblende (brown to green in color) indicate their secondary nature. They appear in kelyphytic coronas around garnet, interstitial to garnet and clinopyroxene, and also in symplectites II. Highly retrograded samples display a characteristic texture of poikiloblastic homblende and plagioclase which contain inclusions of gamet, rutile and quartz.

Greenschist-facies assemblages are preserved only in late shear zones. These consist of albite, chlorite, epidote, actinolitic amphibole, sphene and quartz. Thus, the mineral assemblages and textures of these rocks indicate three main metamorphic stages: of eclogite, amphibolite and greenschist-facies (Fig. 4).

\section{Mineral chemistry}

Chemical analyses of minerals from 9 eclogite samples were carried out with a Camebax automatic microprobe equipped with four spectrometers at the Université des Sciences et Techniques du Languedoc (Montpellier II). The operating parameters were: $10 \mathrm{~s}$ counting time, $15 \mathrm{kV}$ accelerating voltage, $10 \mathrm{nA}$ beam current, and an approximately $2 \mu \mathrm{m}$ beam diameter. Calibration was against BRMG (French Geological Survey) standard minerals, and the ZAF correction procedure was used. Detailed analyses were performed for all the minerals, giving special attention to the micro-inclusions in the garnet and the development of compositional zoning. Only garnet has significant zoning. Tables $1-5$ have representative chemical analyses.

\subsection{Garnet}

Common end members were calculated in garnets using $\mathrm{Fe}^{2+} / \mathrm{Fe}^{3+}$ ratios estimated by charge-balance method on a stoichiometric sum of cations. The idiomorphic nonatoll garnets are almandine rich, with pyrope rich rims and central zones high in grossular component. The mean composition of garnet cores is $\mathrm{Alm}_{47} \mathrm{Grs}_{30} \operatorname{Prp}_{18} \mathrm{Adr}_{3} \mathrm{Sps}_{2}$, whereas that of the rims is $\mathrm{Alm}_{48.5} \operatorname{Prp}_{30} \mathrm{Grs}_{18} \mathrm{Adr}_{3} \mathrm{Sps}_{0.5}$. Compositions of

Fig. 3. Photomicrographs of Agualada Unit eclogites. (a and b) These show eclogite-facies foliation defined by oriented rutile and omphacite grains, the latter subsequently replaced by a symplectite; the bar indicates the orientation of the foliation. (c and d) These illustrate honeycomb patterns within isotropic eclogites; most of the matrix and the inner part of the gamets consist of a retrogressive aggregate, formed by symplectitic clinopyroxene III, homblende, plagioclase, quartz and ilmenite. (e) Atoll gamet with an inclusion of clinopyroxene I; in the upper part of the photograph secondary hormblende has replaced omphacite and contains inclusions of rutile. (f) Clinopyroxene I showing a reaction relationship with host gamet that produced interstitial plagioclase. (g) Symplectite pseudomorph of clinopyroxene I. (h) Coarse-grained symplectite of plagioclase and clinopyroxene III. 
Table 1

Representative garnet analyses (profiles UA-16 and UA-17)

\begin{tabular}{|c|c|c|c|c|c|c|c|c|c|c|c|c|c|c|}
\hline Sample & $16-r$ & $16-\mathrm{cr}$ & $16-\mathrm{cr}$ & $16-c$ & 16-c & $16-\mathrm{cr}$ & $16-r$ & $17-r$ & $17-\mathrm{cr}$ & $17-\mathrm{cr}$ & $17-c$ & $17-c$ & $17-\mathrm{cr}$ & $17-r$ \\
\hline $\mathrm{SiO}_{2}$ & 38.50 & 38.11 & 38.35 & 38.33 & 39.02 & 38.42 & 38.85 & 39.73 & 38.53 & 38.67 & 39.13 & 39.20 & 38.72 & 39.30 \\
\hline $\mathrm{Al}_{2} \mathrm{O}_{3}$ & 22.50 & 22.06 & 21.76 & 22.23 & 21.96 & 22.05 & 22.39 & 22.64 & 21.87 & 21.51 & 21.91 & 22.30 & 21.81 & 22.49 \\
\hline $\mathrm{FeO}$ & 22.86 & 24.83 & 23.99 & 21.68 & 22.31 & 23.23 & 22.95 & 22.58 & 26.86 & 25.87 & 2.12 & 21.83 & 25.62 & 22.59 \\
\hline $\mathrm{MnO}$ & 0.51 & 0.39 & 0.61 & 0.65 & 0.84 & 0.98 & 0.47 & 0.35 & 0.77 & 0.89 & 1.77 & 1.94 & 1.66 & 0.42 \\
\hline $\mathrm{MgO}$ & 7.73 & 3.74 & 3.66 & 5.26 & 5.44 & 3.94 & 7.95 & 7.86 & 2.51 & 2.51 & 4.38 & 4.28 & 2.43 & 7.74 \\
\hline $\mathrm{CaO}$ & 7.56 & 11.19 & 11.99 & 11.78 & 11.63 & 12.43 & 7.54 & 8.34 & 11.29 & 11.80 & 12.16 & 12.34 & 11.99 & 8.46 \\
\hline Total & 99.66 & 100.32 & 100.36 & 99.93 & 101.20 & 101.05 & 100.15 & 101.50 & 101.83 & 101.25 & 101.47 & 101.89 & 102.23 & 101.00 \\
\hline \multicolumn{15}{|c|}{ Cations per 12 oxygens } \\
\hline $\mathrm{Si}$ & 2.956 & 2.966 & 2.982 & 2.958 & 2.977 & 2.959 & 2.967 & 2.991 & 2.985 & 3.009 & 2.995 & 2.987 & 2.986 & 2.976 \\
\hline $\mathrm{Al}^{\mathrm{IV}}$ & 0.044 & 0.034 & 0.018 & 0.042 & 0.023 & 0.041 & 0.033 & 0.009 & 0.015 & 0.000 & 0.005 & 0.013 & 0.014 & 0.024 \\
\hline $\mathrm{Al} \mathrm{I}^{\mathrm{VI}}$ & 1.993 & 1.991 & 1.977 & 1.980 & 1.953 & 1.962 & 1.982 & 2.001 & 1.982 & 1.974 & 1.972 & 1.990 & 1.969 & 1.983 \\
\hline $\mathrm{Fe}^{3+}$ & 0.052 & 0.043 & 0.041 & 0.063 & 0.070 & 0.079 & 0.051 & 0.008 & 0.033 & 0.008 & 0.033 & 0.023 & 0.045 & 0.042 \\
\hline $\mathrm{Fe}^{2+}$ & 1.416 & 1.574 & 1.519 & 1.336 & 1.354 & 1.417 & 1.415 & 1.414 & 1.707 & 1.676 & 1.383 & 1.368 & 1.608 & 1.389 \\
\hline Mn & 0.033 & 0.026 & 0.040 & 0.042 & 0.054 & 0.064 & 0.030 & 0.022 & 0.051 & 0.059 & 0.115 & 0.125 & 0.108 & 0.027 \\
\hline $\mathrm{Mg}$ & 0.884 & 0.434 & 0.424 & 0.605 & 0.619 & 0.452 & 0.905 & 0.882 & 0.290 & 0.291 & 0.500 & 0.486 & 0.279 & 0.873 \\
\hline $\mathrm{Ca}$ & 0.622 & 0.933 & 0.999 & 0.974 & 0.951 & 1.026 & 0.617 & 0.673 & 0.937 & 0.984 & 0.997 & 1.008 & 0.991 & 0.686 \\
\hline Alm & 47.91 & 53.05 & 50.93 & 45.18 & 45.46 & 47.89 & 47.68 & 47.28 & 57.20 & 55.68 & 46.19 & 45.81 & 53.84 & 46.68 \\
\hline Prp & 29.92 & 14.63 & 14.22 & 20.45 & 20.78 & 15.28 & 30.50 & 29.48 & 9.71 & 9.67 & 16.68 & 16.27 & 9.35 & 29.35 \\
\hline And & 2.62 & 2.17 & 2.08 & 3.18 & 3.53 & 4.02 & 2.58 & 0.38 & 1.65 & 0.40 & 1.63 & 1.15 & 2.25 & 2.09 \\
\hline Gro & 18.43 & 29.30 & 31.42 & 29.75 & 28.40 & 30.65 & 18.21 & 22.11 & 29.75 & 32.29 & 31.61 & 32.58 & 30.93 & 20.97 \\
\hline Sps & 1.12 & 0.87 & 1.35 & 1.44 & 1.82 & 2.16 & 1.02 & 0.75 & 1.69 & 1.95 & 3.83 & 4.19 & 3.63 & 0.91 \\
\hline
\end{tabular}

Core (c); rim (r); inner zones (cr). 
garnet cores project into the field for type $\mathrm{C}$ eclogite garnets, whereas the rims plot at the boundary between type B and C fields (Fig. 5).

Idiomorphic garnet grains show pronounced compositional zoning, with an increase in Mg-contents and decreases in $\mathrm{Mn}$ and $\mathrm{Ca}$-contents from core to rim. Such features are generally interpreted to reflect growth zoning (Hollister, 1966; Tracy, 1982; Frost and Tracy, 1991). Detailed zoning profiles reveal a central region enriched in $\mathrm{Mg}$, an intermediate zone in which minimum values of $X_{\mathrm{Mg}}$ are reached, and a gradual increase of $\mathrm{Mg}$-values towards the rim (Fig. 6). $\mathrm{Mn}$ and $\mathrm{Ca}$-contents decrease towards garnet rims. $\mathrm{Fe}$-contents and $\mathrm{Fe} /(\mathrm{Fe}+\mathrm{Mg})$ show an inverse relationship to $\mathrm{Mg}$-contents (Fig. 6). In some garnet grains, a reversal of these zoning trends can be seen in the outermost parts of garnet rims (20-50 $\mu \mathrm{m}$ further out). This is interpreted to reflect retrogressive diffusion. Such retrogressive overprints cause peak temperatures obtained by thermobarometric calculations to be underestimated (Spear, 1991).

The atoll garnets are homogeneous and show compositions similar to those of retrograded rims in larger garnets, suggesting that they were wholly affected by retrogressive re-equilibria, probably due to the thinness of their walls. Small euhedral, nonatoll garnets, less than $0.2 \mathrm{~mm}$ in diameter, are also homogeneous, with similar retrogressive compositions.

\subsection{Clinopyroxene}

The $\mathrm{Fe}^{2+} / \mathrm{Fe}^{3+}$ ratio was estimated by chargebalance after assumption of stoichiometry, and clinopyroxene end members were calculated using the method of Cawthorn and Collerson (1974). These molecular compositions (with maximum jadeite content) have been used in the thermobarometric calcu-

Table 2

Representative clinopyroxene-I analyses

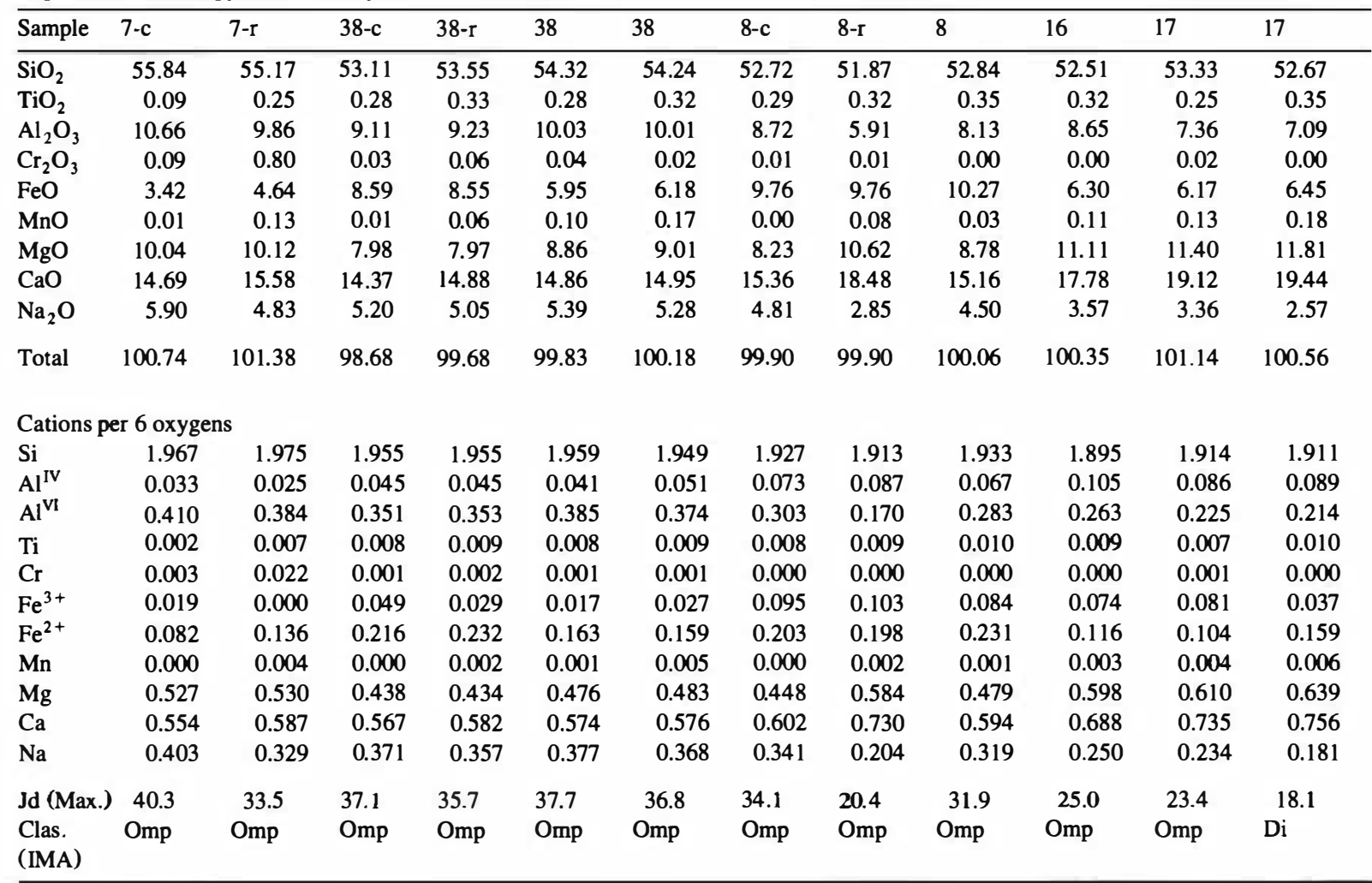

Core (c); rim (r); jadeite (Jd); classification (Clas.). 
lations. However, for pyroxene classification and plotting in diagrams the method of Kushiro (1962) for the calculation of end members was preferred, since with the first procedure zero contents in acmite were always obtained for these clinopyroxenes, whereas with the second, variable contents are obtained (max. $12.6 \mathrm{~mol} \%$ ), which probably provides a more realistic plot.

Clinopyroxene I grains show the largest amounts of jadeite component, from $\mathrm{Jd}_{19}$ to $\mathrm{Jd}_{40}$, with an average composition of $\mathrm{Jd}_{26} \mathrm{Ts}_{7} \mathrm{Wo}_{30} \mathrm{En}_{28} \mathrm{Fs}_{9}$. The maximum jadeite contents appear in grains within completely closed atoll garnet grains, or in small crystals included in the cores of idiomorphic gamets. Minimum jadeite contents are typically observed in crystals in contact with the matrix, which suggests that such grains may have re-equilibrated. Some grains display weak compositional zoning, in which jadeite content decreases between core and rim (Fig.
7A). The $\mathrm{Fe} /(\mathrm{Fe}+\mathrm{Mg})$ ratios of such grains is either unchanged or decreases slightly from core to rim. Clinopyroxenes I presumably retain their original composition, since they are surrounded by gamet and not easily affected by later re-equilibration (O’Brien, 1989).

Clinopyroxenes II grains display jadeite contents of $\mathrm{Jd}_{16}$ to $\mathrm{Jd}_{36}$ with an average molecular composition of $\mathrm{Jd}_{25} \mathrm{Ts}_{7} \mathrm{Wo}_{31} \mathrm{En}_{29} \mathrm{Fs}_{8}$. Their $\mathrm{Fe} /(\mathrm{Fe}+\mathrm{Mg})$ ratio is always larger than that of clinopyroxene $\mathrm{I}$ from the same sample. Compositional zoning has not been detected in clinopyroxene II. Grains of clinopyroxene III range between $\mathrm{Jd}_{11}$ and $\mathrm{Jd}_{23}$. Their $\mathrm{Fe} /(\mathrm{Fe}+\mathrm{Mg})$ ratio is larger than that of clinopyroxene II grains in the same sample. The textural types of clinopyroxenes III (symplectitic versus granoblastic to tabular) show no significant differences in composition.

Clinopyroxene I and II are omphacite and sodic

Table 3

Representative clinopyroxene analyses (types II and III)

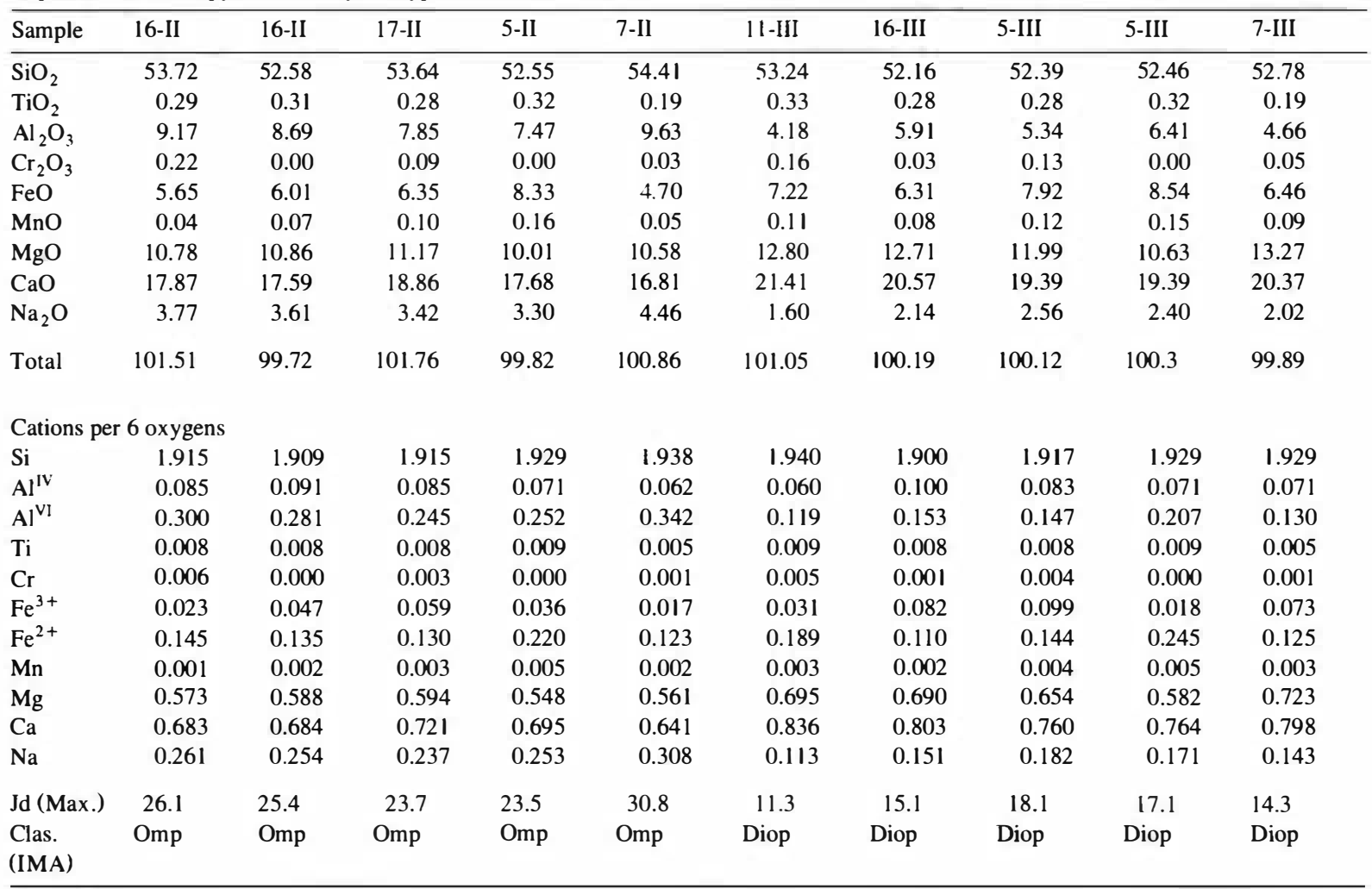

Clinopyroxene-II (I1); clinopyroxene-III (III); jadeite (Jd); classification (Clas.). 
diopside (Essene and Fyfe, 1967; Rossi, 1988) (Fig. 7A and B); whereas clinopyroxene III is sodic diopside (Fig. 7C). There is, therefore, a compositional evolution from clinopyroxene I to clinopyroxene III, with a slight decrease in jadeite contents (Fig. 7D) and increase in $X_{\mathrm{Fe}}(\mathrm{Fe} /(\mathrm{Fe}+\mathrm{Mg}))$.

\subsection{Amphibole}

The structural formulae were calculated by assuming total cations equal to 13 (except $\mathrm{Ca}, \mathrm{Na}$ and $\mathrm{K}$ ) (Leake, 1978; Spear and Kimball, 1984). Compositions of brown calcic amphibole grains are tschermakitic homblende, pargasite and $\mathrm{Mg}$-hastingsitic homblende. Their relatively high $\mathrm{TiO}_{2}$ and $\mathrm{Al}_{2} \mathrm{O}_{3}$ contents and moderate $\mathrm{Na}(\mathrm{A})$ and $\mathrm{Na}(\mathrm{M} 4)$ contents, suggest a relatively high crystallization temperature at intermediate pressures. Green $\mathrm{Ca}$-amphibole display Mg-homblende compositions. These grains show lower contents of $\mathrm{TiO}_{2}, \mathrm{Al}_{2} \mathrm{O}_{3}$ and $\mathrm{Na}_{2} \mathrm{O}$, and higher contents of $\mathrm{SiO}_{2}$ with respect to brown amphibole.

\subsection{Plagioclase}

Different textural types of secondary plagioclase were analyzed. All are of a low $\mathrm{K}_{2} \mathrm{O}$-content ( $\mathrm{Or}=$ 0-1.5 mol\%). Plagioclase from symplectites with clinopyroxene or in fine grained coronas around garnet are oligoclase, ranging from $\mathrm{An}_{11}$ to $\mathrm{An}_{22}$. Plagioclase that occurs as poikiloblasts in the matrix, and which contains inclusions of garnet and rutile, ranges in composition from $\mathrm{An}_{9}$ to $\mathrm{An}_{13}$.

\subsection{Epidote-group minerals}

Zoisite and clinozoisite grains in the matrix and later epidote in veins and fracture zones were ana-

Table 4

Representative amphibole analyses

\begin{tabular}{|c|c|c|c|c|c|c|c|c|c|c|}
\hline Sample & $1-b$ & $5-b$ & 7-b & $8-b / c$ & $8-b / r$ & $1-g$ & $7-g$ & $12-g$ & $17-g$ & 17-cl \\
\hline $\mathrm{SiO}_{2}$ & 43.50 & 42.77 & 44.22 & 43.29 & 44.38 & 49.22 & 49.34 & 45.87 & 45.68 & 51.12 \\
\hline $\mathrm{TiO}_{2}$ & 1.12 & 1.66 & 1.16 & 1.69 & 1.76 & 0.54 & 0.05 & 0.11 & 0.72 & 0.20 \\
\hline $\mathrm{FeO}$ & 11.04 & 13.63 & 10.12 & 15.73 & 16.14 & 14.23 & 12.53 & 19.19 & 11.35 & 19.12 \\
\hline $\mathrm{MnO}$ & 0.10 & 0.04 & 0.15 & 0.17 & 0.15 & 0.55 & 0.17 & 0.16 & 0.06 & 0.45 \\
\hline $\mathrm{MgO}$ & 13.62 & 12.27 & 14.42 & 11.73 & 11.70 & 13.37 & 13.97 & 9.74 & 14.34 & 11.48 \\
\hline $\mathrm{K}_{2} \mathrm{O}$ & 1.06 & 1.11 & 0.83 & 0.19 & 0.42 & 0.22 & 0.25 & 0.20 & 0.51 & 0.08 \\
\hline Total & 98.65 & 97.30 & 98.29 & 98.18 & 98.55 & 98.16 & 100.60 & 97.92 & 100.60 & 99.08 \\
\hline \multicolumn{11}{|c|}{ Cations $=13($ except $\mathrm{Ca}, \mathrm{Na}, \mathrm{K})$} \\
\hline $\mathrm{Fe}^{3+}$ & 0.550 & 0.742 & 0.664 & 0.811 & 0.806 & 0.460 & 0.197 & 0.531 & 0.197 & 0.453 \\
\hline $\mathrm{Mg}$ & 2.901 & 2.671 & 3.054 & 2.539 & 2.530 & 2.873 & 2.920 & 2.150 & 2.920 & 2.488 \\
\hline $\mathrm{Fe}^{2+}$ & 0.770 & 0.922 & 0.539 & 1.099 & 1.153 & 1.257 & 1.273 & 1.846 & 1.273 & 1.872 \\
\hline $\mathrm{Mn}$ & 0.012 & 0.005 & 0.018 & 0.021 & 0.020 & 0.067 & 0.020 & 0.020 & 0.020 & 0.055 \\
\hline $\mathrm{Ca}$ & 1.717 & 1.685 & 1.639 & 1.659 & 1.603 & 1.845 & 1.957 & 1.970 & 1.957 & 1.906 \\
\hline $\mathrm{Na}(\mathrm{M} 4)$ & 0.283 & 0.315 & 0.361 & 0.341 & 0.397 & 0.155 & 0.043 & 0.030 & 0.043 & 0.094 \\
\hline $\mathrm{Na}(\mathrm{A})$ & 0.435 & 0.277 & 0.413 & 0.391 & 0.391 & 0.155 & 0.286 & 0.202 & 0.286 & 0.038 \\
\hline K & 0.193 & 0.207 & 0.151 & 0.035 & 0.078 & 0.040 & 0.045 & 0.038 & 0.045 & 0.015 \\
\hline
\end{tabular}

Brown (b); green (g); colorless (cl); core (c); rim (r). 
Table 5

Representative analyses of plagioclases, epidotes and $\mathrm{Fe}-\mathrm{Ti}$ oxides

\begin{tabular}{|c|c|c|c|c|c|c|c|c|c|c|c|c|c|c|}
\hline Sample & $16-s$ & $16-s$ & $5-s$ & $5-c$ & $5-g$ & $8-g$ & $1-20$ & $1-c z o$ & 5-ep & 17-ер & $17-r$ & 16-il & $17-i 1$ & $16-\mathrm{h}$ \\
\hline$\overline{\mathrm{SiO}_{2}}$ & 62.54 & 62.17 & 64.12 & 64.68 & 66.78 & 66.74 & 39.42 & 39.73 & 38.19 & 38.28 & 0.43 & 0.54 & 0.40 & 0.83 \\
\hline $\mathrm{TiO}_{2}$ & 0.00 & 0.00 & 0.00 & 0.00 & 0.00 & 0.00 & 0.05 & 0.01 & 0.05 & 0.00 & 100.94 & 53.87 & 54.47 & 0.00 \\
\hline $\mathrm{Al}_{2} \mathrm{O}_{3}$ & 22.05 & 22.59 & 21.52 & 21.44 & 20.95 & 21.18 & 32.40 & 32.59 & 24.85 & 24.85 & 0.01 & 0.00 & 0.00 & 0.29 \\
\hline $\mathrm{FeO}$ & 0.19 & 0.23 & 0.16 & 0.19 & 0.00 & 0.16 & 1.94 & 1.64 & 12.22 & 11.58 & 0.51 & 45.11 & 45.54 & 70.91 \\
\hline $\mathrm{MnO}$ & 0.00 & 0.00 & 0.00 & 0.00 & 0.00 & 0.00 & 0.00 & 0.00 & 0.09 & 0.15 & 0.00 & 1.21 & 0.39 & 0.00 \\
\hline $\mathrm{MgO}$ & 0.00 & 0.00 & $0 .(0)$ & 0.00 & 0.00 & 0.00 & 0.00 & 0.05 & 0.00 & 0.01 & 0.00 & 0.17 & 0.68 & 0.00 \\
\hline $\mathrm{CaO}$ & 3.11 & 4.15 & 2.74 & 2.30 & 1.94 & 1.91 & 24.31 & 24.35 & 23.68 & 23.83 & & & & \\
\hline $\mathrm{Na}_{2} \mathrm{O}$ & 9.04 & 8.37 & 9.57 & 9.67 & 10.40 & 9.77 & 0.00 & $0 .(1) 0$ & 0.00 & 0.03 & & & & \\
\hline $\mathrm{K}_{2} \mathrm{O}$ & 0.19 & 0.00 & 0.06 & 0.00 & 0.17 & 0.01 & 0.02 & 0.01 & 0.00 & 0.02 & & & & \\
\hline Total & 97.12 & 97.51 & 98.17 & 98.28 & 100.24 & 99.77 & 98.14 & 98.38 & 99.08 & 98.52 & 101.89 & 100.90 & 101.48 & 72.03 \\
\hline $\mathrm{Si}$ & 2.835 & 2.809 & 2.871 & 2.886 & 2.921 & 2.924 & 2.997 & 3.006 & 2.993 & 3.004 & 0.01 & 0.01 & 0.01 & 0.03 \\
\hline $\mathrm{Ti}$ & 0.000 & 0.000 & 0.000 & 0.000 & 0.000 & 0.000 & 0.002 & 0.000 & 0.003 & 0.000 & 1.98 & 1.02 & 1.03 & 0.00 \\
\hline Al & 1.179 & 1.203 & 1.136 & 1.128 & 1.080 & 1.094 & 2.901 & 2.907 & 2.297 & 2.299 & 0.00 & 0.00 & 0.00 & 0.01 \\
\hline $\mathrm{Fe}^{3}$ & & & & & & & 0.109 & 0.086 & 0.715 & (1).682 & 0.00 & 0.0() & (). 00 & 1.92 \\
\hline $\mathrm{Fe}^{2+}$ & 0.007 & 0.009 & 0.006 & 0.007 & 0.000 & 0.006 & & & & & 0.01 & 0.9 .5 & 0.95 & 0.04 \\
\hline $\mathrm{Mn}$ & 0.000 & 0.000 & 0.000 & 0.000 & 0.000 & 0.000 & 0.000 & 0.000 & 0.006 & 0.009 & 0.00 & 0.03 & 0.01 & 0.00 \\
\hline $\mathrm{Mg}$ & 0.000 & 0.000 & 0.00() & 0.000 & 0.000 & 0.000 & 0.000 & 0.004 & 0.000 & 0.000 & & & & \\
\hline $\mathrm{Ca}$ & 0.151 & 0.201 & 0.131 & 0.110 & 0.091 & 0.090 & 1.977 & 1.973 & 2.080 & 0.005 & & & & \\
\hline $\mathrm{Na}$ & 0.795 & 0.733 & 0.831 & 0.837 & 0.882 & 0.830 & 0.000 & 0.000 & 0.000 & 0.010 & & & & \\
\hline $\mathbf{K}$ & 0.011 & 0.000 & 0.003 & 0.000 & 0.009 & 0.001 & 0.003 & 0.000 & 0.000 & 0.000 & & & & \\
\hline An & 15.79 & 21.51 & 13.61 & 11.61 & 9.25 & 9.74 & & & & & & & & \\
\hline $\mathrm{Ab}$ & 83.06 & 78.49 & 86.03 & 88.38 & 89.78 & 90.19 & & & & & & & & \\
\hline Or & 1.15 & 0.00 & 0.35 & 0.00 & 0.99 & 0.06 & & & & & & & & \\
\hline $\mathrm{FeAlO}_{3}$ & & & & & & & & & & & 0.02 & 0.00 & 0.00 & 1.13 \\
\hline $\mathrm{FeSiO}_{3}$ & & & & & & & & & & & 0.56 & 1.32 & 0.97 & 2.74 \\
\hline Pyrophanite & & & & & & & & & & & 0.00 & 2.50 & 0.80 & 0.00 \\
\hline Ilmenite & & & & & & & & & & & 0.00 & 90.58 & 91.11 & 0.00 \\
\hline Hematite & & & & & & & & & & & 0.00 & 0.00 & 0.00 & 96.12 \\
\hline Rutile & & & & & & & & & & & 99.44 & 5.61 & 7.13 & 0.00 \\
\hline
\end{tabular}

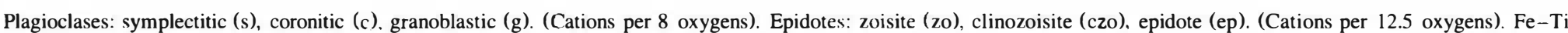
oxides: rutile $(r)$, ilmenite $(i l)$, hematite $(h) .($ Cations $=2)$. 


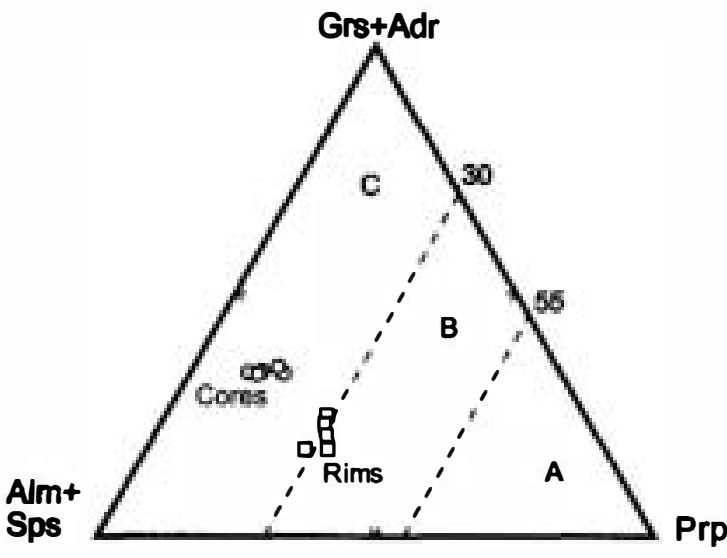

Fig. 5. Core and rim compositions of gamet from the Agualada Unit eclogites; diagram after Coleman et al. (1965).

lyzed. The zoisite and clinozoisite from eclogite and amphibolite matrixes are found as prismatic crystals. They show compositions characteristic of almost pure $\mathrm{Al}$ end members (pistacite $<5 \mathrm{~mol} \%$ ). In contrast, epidote grains from late veins and fractures display contents of pistacite from 22 to $24 \mathrm{~mol} \%$.

\subsection{Fe-Ti oxide minerals}

$\mathrm{Fe}^{3+}$ contents and molecular norms were calculated according to the method of Rumble (1973).
Petrographically identified rutile grains are almost pure $\mathrm{TiO}_{2}$. The opaque minerals which surround some rutile grains are ilmenite (ilmenite $=86-96$ mol\%), with pyrophanite (Mn-ilmenite) contents ranging between $1.5-2.5 \mathrm{~mol} \%$. Opaque matrix crystals of ilmenite contain less pyrophanite component than those that surround rutile grains. Hematite crystals appear to be texturally later than matrix ilmenite, and related to an increase in the $\mathrm{fO}_{2}$; the presence of epidote in the retrograde assemblages seems to indicate the same.

\section{Mineral assemblages and chemical equilibrium}

\subsection{Eclogite-facies stage: Mineral assemblages with omphacite + garnet}

The eclogite mineral assemblage of omphacite + garnet + quartz + rutile \pm zoisite represents a moreor-less prolonged tectonothermal evolution. Two events are recorded by this assemblage. The first is represented by inclusions of clinopyroxene I, rutile and quartz in cores of gamet grains. A later assemblage consists of matrix clinopyroxene II and the maximum $X_{\mathrm{Mg}}$ contents of garnet (prograde rims).
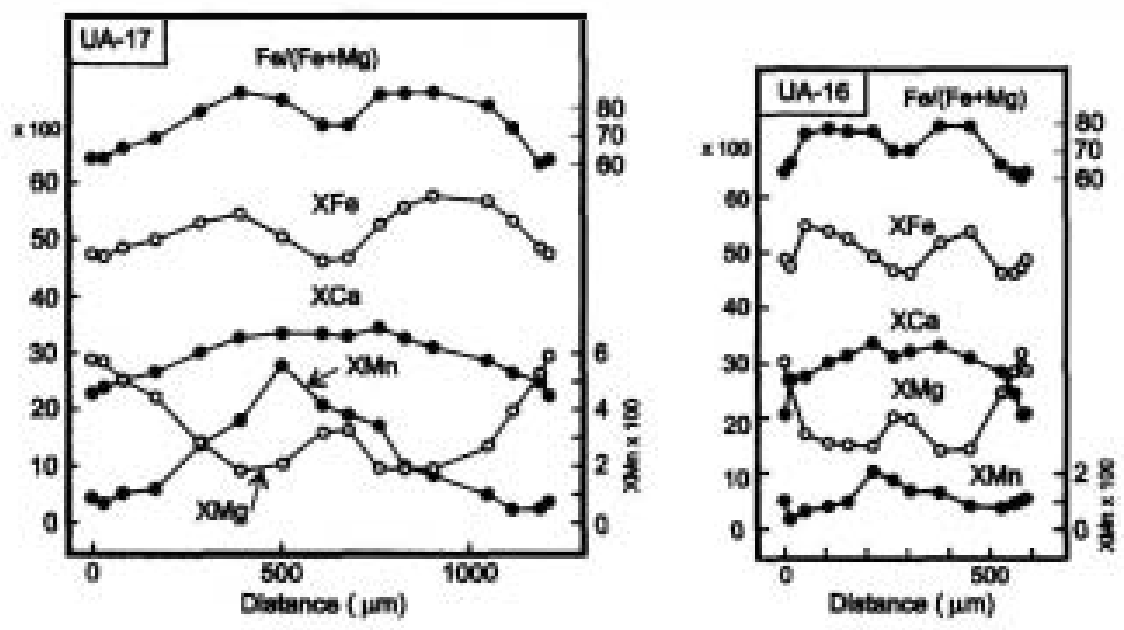

Fig. 6. Compositional profiles of two idiomorphic garnets from the Agualada Unit eclogites (samples UA-16 and UA-17), The mole fractions are multiplied by 100 . 


\subsubsection{Early eclogite mineral assemblage}

Cores of gamet grains show two chemically distinct zones: (1) a central region enriched in $X_{\mathrm{Mg}}$, and (2) an intermediate zone in which $X_{\mathrm{Mg}}$ decreases to a minimum value (Figs. 6 and 8). We interpret this discontinuous zoning to reflect two parageneses that formed prior to crystallization of clinopyroxene II:

(A) Clinopyroxene I + gamet (central region) + quartz + rutile;

(B) Clinopyroxene I + gamet (intermediate zone. $\left.\min . X_{\mathrm{Mg}}\right)+$ quartz + rutile.

Only one composition of clinopyroxene I was considered, because crystals only reveal slight zoning, with rims somewhat poorer in $\mathrm{Na}_{2} \mathrm{O}$ and also a slight decrease in $\mathrm{Fe} /(\mathrm{Fe}+\mathrm{Mg})$.

\subsubsection{Late eclogite mineral assemblage}

This assemblage consists of matrix clinopyroxene II and gamet rims that contain maximum $X_{\mathrm{Mg}}$. Textural relationships between clinopyroxene and

(A)

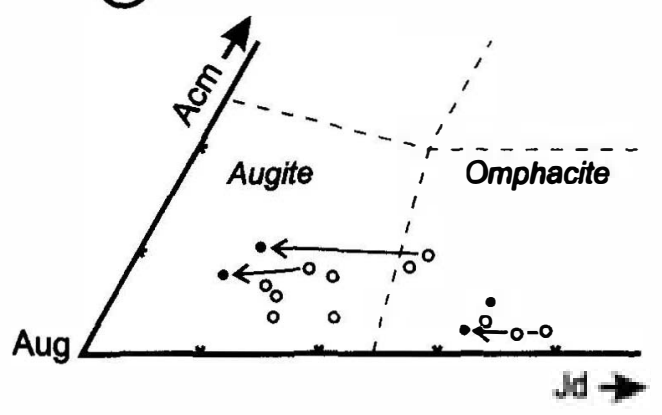

(C)

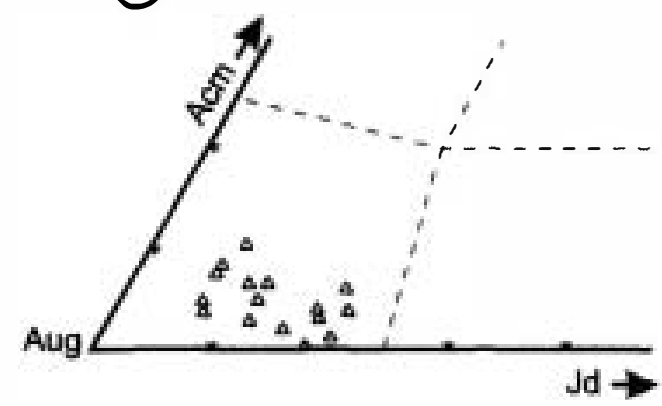

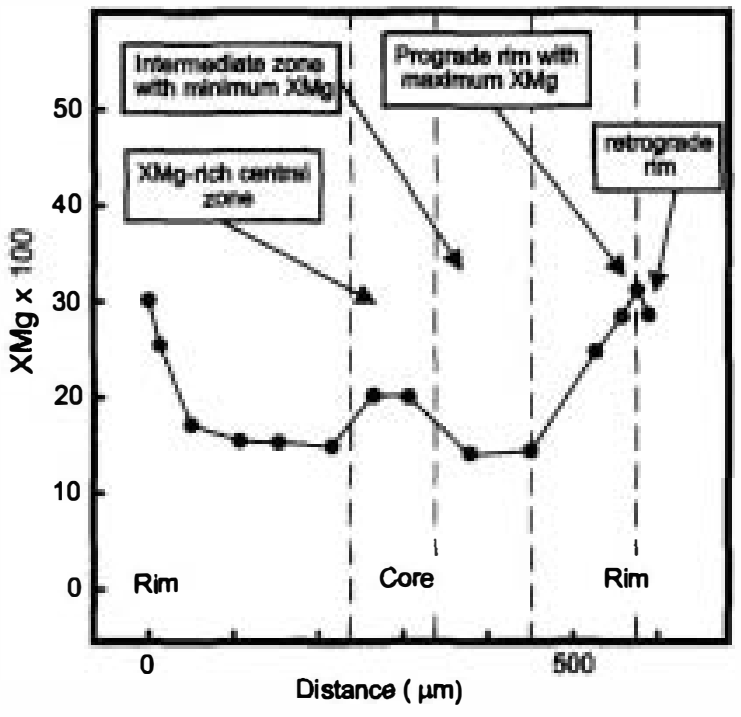

Fig. 8. Characteristic zones of the eclogitic garnets, based on the Mg-compositional profile of sample UA-16.

\section{(B)}
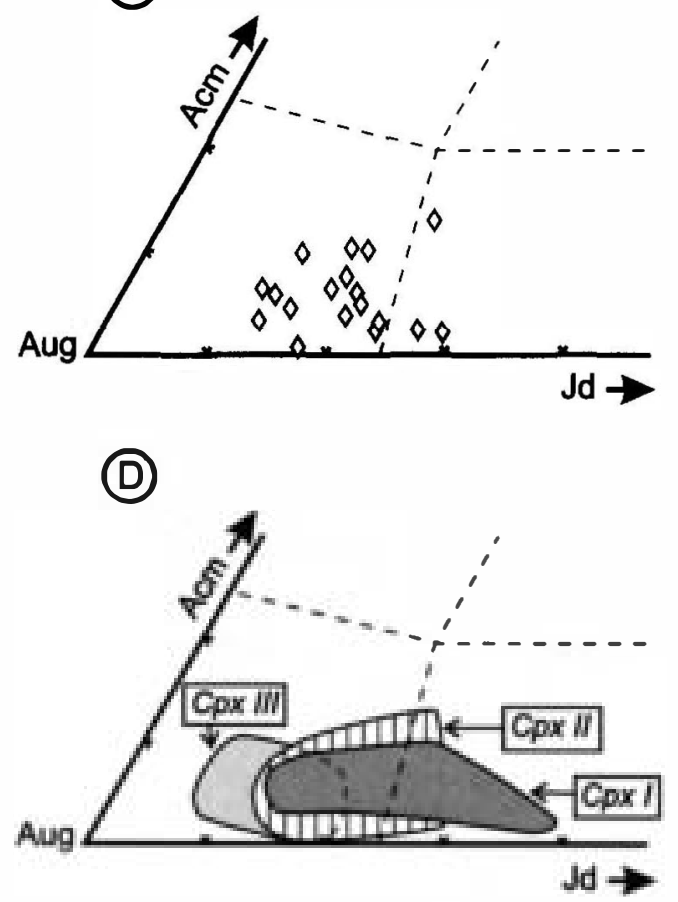

Fig. 7. Chemical variability of clinopyroxene in the Agualada Unit eclogites. (A) Clinopyroxene I; the arrows indicate the compositional variation from cores to rims (black dots). (B) Clinopyroxene II. (C) Clinopyroxene III (secondary). (D) Fields defined by the composition of the three types of clinopyroxenes. Diagram after Essene and Fyfe (1967). 
garnet, which, when not affected by retrogressive reactions consist of sharp grain boundaries, suggest that chemical equilibrium was reached. We interpret this assemblage to reflect the paragenesis:

(C) Clinopyroxene II + gamet (prograde rim, max. $\left.X_{\mathrm{Mg}}\right)+$ quartz + rutile \pm zoisite.

\subsection{Amphibolite-facies stage}

Amphibolite-facies assemblages appear to replace the eclogitic assemblages. They also record the earliest development of regional foliation in the Agualada Unit. Two amphibolite-facies parageneses reflect local chemical equilibria: (1) gamet rims and amphibolite-facies clinopyroxene and (2) gamet rims and hornblende:

(D) Clinopyroxene $\mathrm{III}+$ garnet (retrograde rim) + brown amphibole + plagioclase $\left(\mathrm{An}_{11}-\mathrm{An}_{22}\right)+$ clinozoisite + quartz + ilmenite \pm zoisite.

(E) Gamet (retrograde rim) + green amphibole + plagioclase $\left(A n_{9}-A n_{13}\right)+$ clinozoisite + quartz + ilmenite.

Mineral assemblage (E) postdates the older, higher grade, paragenesis (D).

\subsection{Greenschist-facies stage}

A greenschist-facies assemblage is found only in narrow shear bands and veins. It consists of:

(F) Actinolitic amphibole + chlorite + epidote + albite + quartz + sphene.

\section{Thermobarometry}

Two eclogite samples that show representative garnet profiles (UA-16 and UA-17; Fig. 6) and all three types of clinopyroxene were studied in detail, along with a third sample (UA-7) that lacks clinopyroxene $\mathrm{I}$. The $P-T$ conditions of the amphibolitefacies assemblages were estimated from observations in eight samples.

In the determination of $P-T$ paths in complex metamorphic rocks, as in the case of eclogites, significant uncertainties result from the choice of equilibrium assemblages for geothermobarometric estimates. Thence, the mineral assemblages defined in the Agualada eclogites were firstly selected on the basis of textural and thermodynamic compatibilities. Recurrence in different samples of $P-T$ determinations for a given mineral assemblage was considered an additional evidence of chemical equilibrium. In the different samples of the Agualada Unit eclogites, the thermobarometry of the eclogite-facies mineral assemblages provides consistent results within a rather limited $P-T$ range. Nevertheless, $P-T$ estimations for the amphibolite-facies assemblages yield scattered results, indicative of less well constrained equilibrium conditions, which must be essentially considered as reference values.

\subsection{Eclogite-facies stage}

The garnet-clinopyroxene geothermometer, as calibrated by Råheim and Green (1974), Ellis and Green (1979), Powell (1985) and Krogh (1988), was used to deduce $P-T$ conditions of this stage. The highest temperatures were calculated with the calibration of Ellis and Green (1979), but those considered most consistent with the general evolution of the eclogites were obtained with the calibration of Krogh (1988), which gave temperatures somewhat lower than the other methods. This geothermometer was used in combination with the barometer of Holland $(1980,1983))$, based on the albite $=$ jadeite + quartz reaction. The absence of plagioclase in the eclogitic parageneses indicates that these pressures are minima.

\subsubsection{Assemblages $A$ and $B$}

For assemblage A, equilibrium conditions of $T=$ 578-590 ${ }^{\circ} \mathrm{C}$ and $P>12-13 \mathrm{kbar}$ were obtained. For mineral assemblage $\mathrm{B}$ lower $P-T$ conditions of $T=$ $485-508^{\circ} \mathrm{C}$ and $P>11-12 \mathrm{kbar}$ were calculated. The consideration of core or rim compositions of clinopyroxene $I$ in mineral assemblage $B$, does not significantly modify the lower $P-T$ conditions deduced for this episode. Therefore, considering the slight and non-systematic nature of zoning in clinopyroxene I, core compositions were always used, both in assemblages $\mathrm{A}$ and $\mathrm{B}$.

\subsubsection{Assemblage $C$}

Peak temperatures for mineral assemblage $C$ were calculated using clinopyroxene II-garnet (prograde rim) pairs. For assemblage $C$ equilibrium conditions 
of $T=655-736^{\circ} \mathrm{C}$ and $P>12-14$ kbar were obtained. These relatively high temperatures are consistent with the field relationship of eclogite boudins within gneisses that displays migmatization. They also support a cofacial relationship between the eclogites and their gneissic host. $P-T$ data obtained for the different eclogite-facies mineral assemblage are plotted in Fig. 9.

\subsection{Amphibolite-facies stage}

\subsubsection{Assemblage D}

Temperature was calculated using the garnetclinopyroxene (Krogh, 1988) and garnet-hornblende (Graham and Powell, 1984) thermometers. By applying the first thermometer to garnet (retrograde rim) and clinopyroxene III (including all the secondary textural types), a wide dispersal of values (492$740^{\circ} \mathrm{C}$ ) was obtained, probably indicating a local lack of equilibrium between these minerals. Taking into account that in the amphibolite-facies clinopyroxene is only stable at relatively high temperatures, values below $600^{\circ} \mathrm{C}$ were not considered as represen-

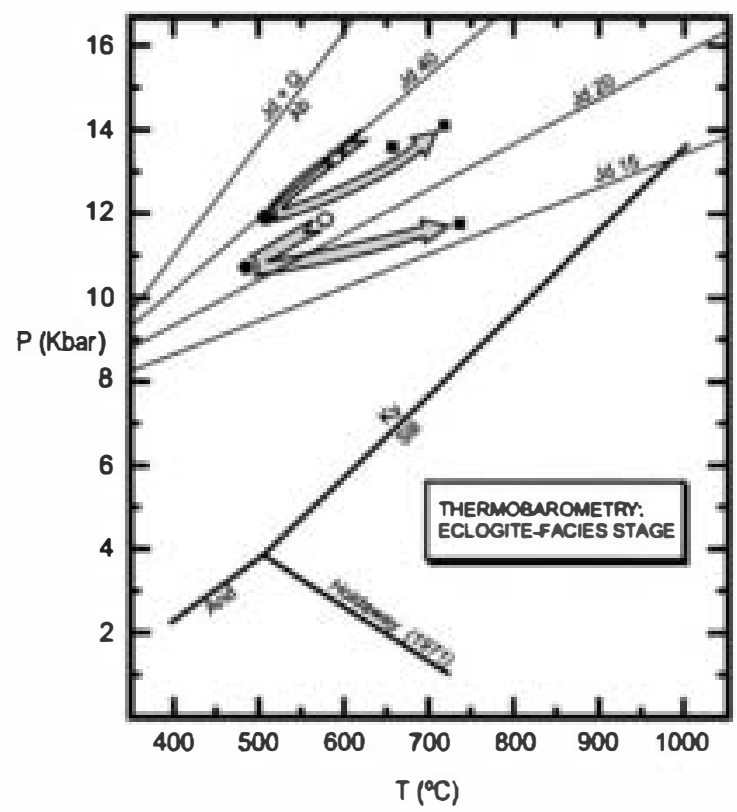

Fig. 9. Suggested thermobarometry for the eclogite-facies stage. Open circles, early eclogite-facies episode (mineral assemblage A); black circles, early eclogite-facies episode (mineral assemblage B); squares, late eclogite-facies episode. Explanation in text.

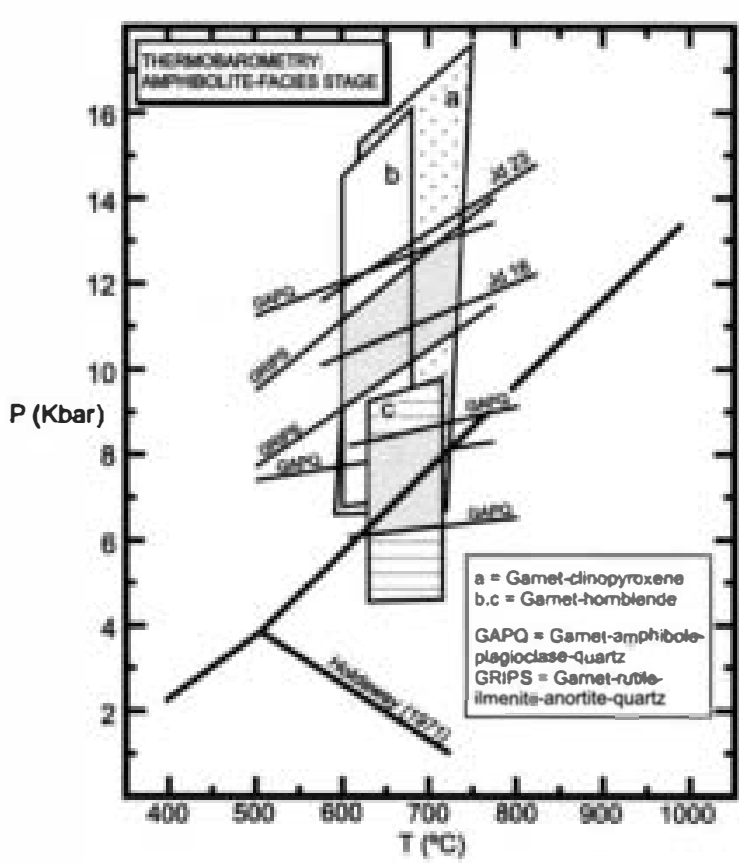

Fig. 10. Thermobarometry for the amphibolite-facies stage (stage I (a and b), stage II (c)). Explanation in text.

lative. The garnet-hornblende thermometer gave rather lower temperatures $\left(595-679^{\circ} \mathrm{C}\right)$. In order to estimate the pressure, three geobarometers were used: jadeite content of the clinopyroxene (Holland, 1980, 1983); garnet-amphibole-plagioclase-quartz (Kohn and Spear, 1989); and garnet-rutile-ilmeniteanorthite-quartz (GRIPS) (Bohlen and Liotta, 1986). Fig. 10 shows the straight lines that these barometers define with their maximum dispersal and their intersection with the thermometers. The region of maximum overlap of the barometers in the range of temperatures considered defines a polygon centered at $T=680^{\circ} \mathrm{C}$ and $P=11.4 \mathrm{kbar}$. Consistent results, though in the lower part of the range given by other barometers, were obtained with the Grt-Cpx-Pl-Qtz barometer (Moecher et al., 1988). For the $T$ interval of the amphibolite-facies stage, $P$ determinations cluster around 8-9 kbar, without significant differences between clinopyroxene III-bearing granoblastic and symplectitic assemblages.

\subsubsection{Assemblage $E$}

Temperature was estimated using the garnethornblende thermometer (Graham and Powell, 1984) 
on green amphibole-gamet retrograde rim pairs, and temperatures generally ranging between 629 and $719^{\circ} \mathrm{C}$ were obtained. Some temperature values obtained with this thermometer were too high (above $830^{\circ} \mathrm{C}$ ), thus inconsistent with the petrographic observations and suggesting the existence of local disequilibrium. Pressure was calculated with the garnet-amphibole-plagioclase-quartz barometer of Kohn and Spear (1989), giving as a result a polygon centered at $675^{\circ} \mathrm{C}$ and $P=7.2 \mathrm{kbar}$ (Fig. 10).

Graham and Powell (1984) point out that in the eclogitic amphibolites there is generally no equilibrium between garnet and amphibole. In this case, the composition of the garnet retrograde rims was used, assuming that re-equilibration was established between this mineral, homblende and clinopyroxene. Hence, it is considered that results obtained in this way, excluding those which clearly indicate disequilibrium of the considered pair of minerals, can be essentially representative of the conditions under which the decompression of the eclogites occurred. The results of the thermobarometry for the amphibolitic stages should, therefore, be considered with some caution.

\section{8. $P-T$ path and tectonic interpretation}

The final part of the eclogite $P-T$ path must cross the stability field of andalusite, because this is a characteristic mineral of contact aureoles around late-tectonic plutons that intrude the basal units. Moreover, the Agualada paragneisses, cofacial with the eclogites, display kyanite and biotite as part of a decompressive foliation, but lack sillimanite; hence, the path must not cross into the sillimanite stability field. The $P-T$ path obtained with thermobarometry reveals a complex eclogitic evolution and a subsequent, almost isothermal decompression (Fig. 11). The preserved syneclogitic $P-T$ path begins with a

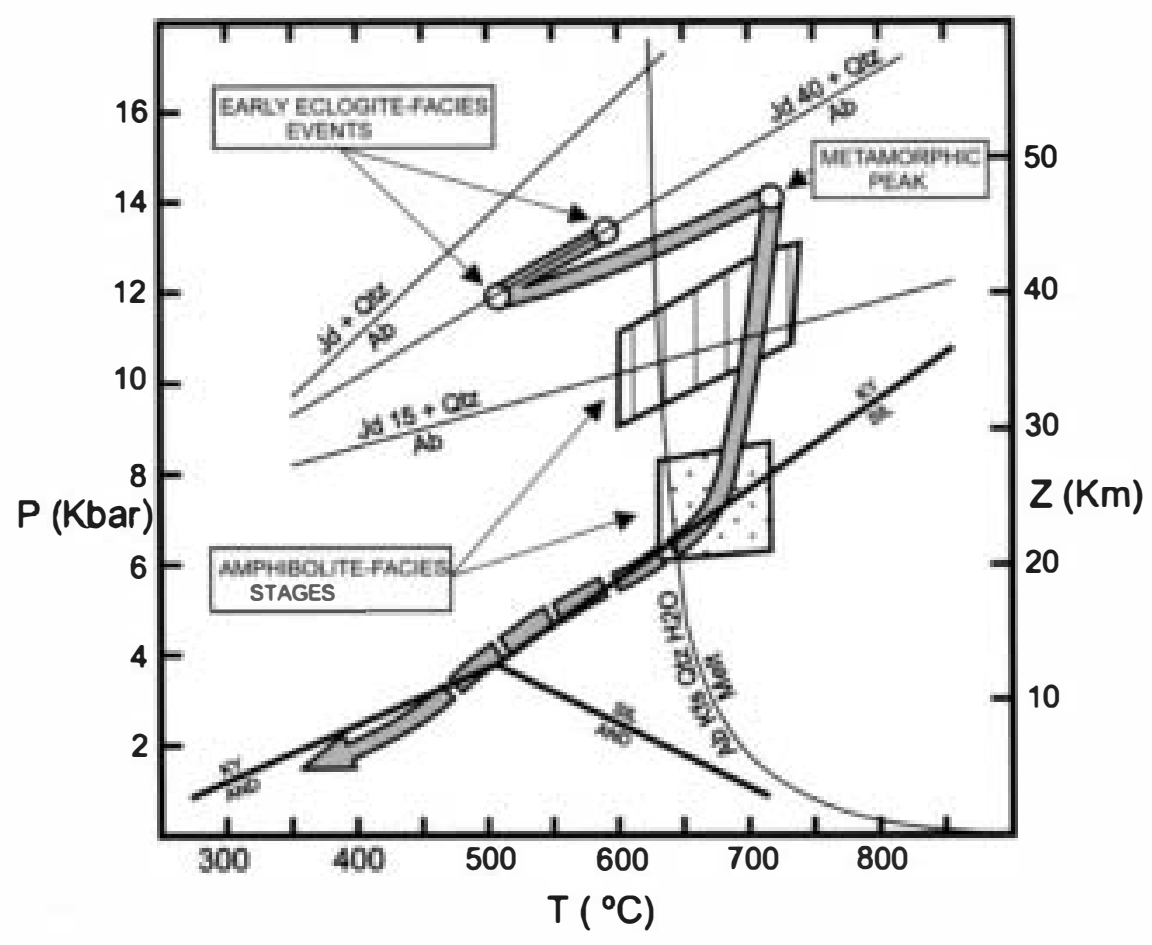

Fig. 11. P-T path deduced for the Agualada Unit eclogites. The obtained results from thermobarometry are also shown, dots and confidence polygons being used for the eclogite and the amphibolite-facies stages, respectively. $\mathrm{Stability}$ of the $\mathrm{Al}_{2} \mathrm{SiO}_{5}$ polymorphs according to Holdaw ay (1971); isopleths of jadeite molecular content in the clinopyroxene according to Holland (1980, 1983); melting curve of wet granitic compositions according to Luth et al. (1964). 
first metamorphic event $\left(T \simeq 585^{\circ} \mathrm{C} ; \quad P>12-13\right.$ kbar), followed by a significant cooling $\left(T \simeq 500^{\circ} \mathrm{C}\right)$ probably with slight decompression $(P>11-12$ kbar), and a subsequent slightly compressive thermal progradation, which defines the $P-T$ path to the metamorphic peak $\left(T=700^{\circ} \mathrm{C} ; \quad P>12-14 \mathrm{kbar}\right)$
(Figs. 9 and 11). However, the $P-T$ evolution deduced for the eclogite-facies stage is affected by some uncertainty, which arises from the minimum character of the pressures obtained with the eclogitic mineral assemblages. Nevertheless, in accordance with the low influence of $P$ on the garnet-clino-

w

E

$\mathrm{Km}$
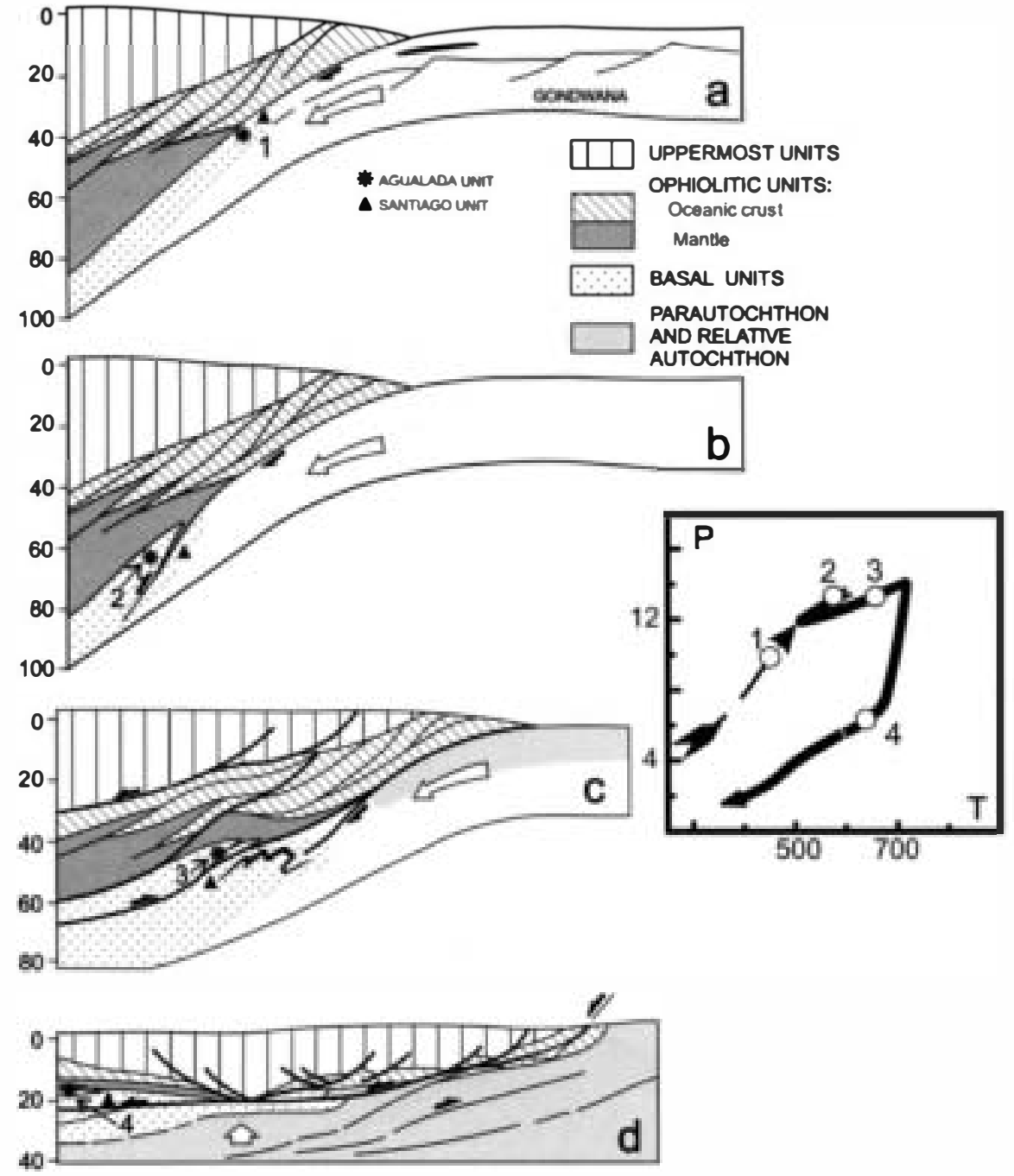

Fig. 12. Schematic model for the dynamic evolution of the Agualada Unit in relation to the $\boldsymbol{P}-\boldsymbol{T}$ path obtained for the eclogites (based on the general model proposed by Martínez Catalán et al., 1996, for the evolution of the Variscan orogenic wedge in the northwest Iberian Massif). The asterisk and the triangle show the successive positions in which the Agualada and Santiago Units, respectively, are found. Numbers $1-4$ of the $\boldsymbol{P}-\boldsymbol{T}$ diagram approximately correspond to evolutive stages $(\mathrm{a}-\mathrm{d})$ in the cross section of the orogenic wedge. (a) Beginning of subduction in the Gondwana continental margin; (b) imbrication between the Agualada and Santiago Units; (c) heating of the Agualada Unit by conductive heat transpor from the overlying mantle wedge and commencement of extension in the orogenic wedge through normal detachments; (d) uplift of the Agualada Unit. 
pyroxene thermometer (Ellis and Green, 1979; Krogh, 1988), this uncertainty should not affect significantly the obtained temperatures. The metamorphic events are related to the general structural evolution deduced for the Ordenes Complex. A reconstruction of the Variscan orogenic wedge in northwest Iberian Massif is described by Martínez Catalán et al. (1996); in this model a westward polarity of the eo-Hercynian subduction is proposed. The subduction culminated in the development of an accretionary complex (affecting the Gondwana margin), which thickened by continued underplating at its base. In this context, the basal units represent the most deeply subducted part of the continental margin, affected by high- $P$ metamorphism, subsequently thrusted over more external parts of the crustal ensemble (Fig. 12). The intense thickening generated in the orogenic wedge was compensated by extensional detachments, which define many of the main tectonic boundaries between units in the Ordenes Complex (Fig. 12).

The Agualada Unit was thrust over a high- $P$ unit with a lower- $T$ metamorphic evolution, the Santiago Unit. Its eclogites were metamorphosed at conditions of $T=495^{\circ} \mathrm{C}$ and $P>14.7 \mathrm{kbar}$ (Arenas et al., 1995). This suggests that eclogite-facies cooling of the Agualada Unit may have been caused by underthrusting of the cooler Santiago Unit, which should have induced a temperature decrease in the hanging wall (Davy and Gillet, 1986). Also according to this model, the thermal disturbance induced in a unit by the underthrusting of another is more efficient when the thickness of the upper unit is low, as is the case of the Agualada Unit. The subsequent increase in temperature recorded by garnet rims and clinopyroxene II may reflect the emplacement of the Agualada Unit directly under the mantle wedge, which should create an inverted metamorphic gradient (Toksöz et al., 1971; Peacock, 1990; Peacock et al., 1994). The thermal disequilibrium between the Agualada Unit and the overlying mantle wedge must have favored conductive heat transfer, probably sufficient to account for the intense heating produced in the unit after imbrication, which led it to reach the thermal peak while still under eclogitic conditions. This may explain why the Agualada Unit displays high- $P$, high- $T$ mineral assemblages, in contrast to the high$P$, low-to moderate- $T$ conditions manifested else- where in the basal units (Malpica-Tuy Unit, Gil Ibarguchi and Ortega Gironés, 1985; Santiago Unit, Arenas et al., 1995; Lalín and Forcarei units, Martínez Catalán et al., 1996). In accordance with the deduced $P-T$ path, the heating induced by the mantle wedge probably was accompanied by slight pressurization, suggesting that burial continued in both units during a certain time after their imbrication, perhaps until the accretion of new units at the base of the pile (through continued underplating) ended in the blocking of subduction and the general uplift of the high- $P$ units, in accordance with the model presented in Fig. 12. In detail, the general evolution of the orogenic wedge, of which the Agualada Unit is part, fairly accurately reproduces the dynamic model proposed by Platt $(1986,1987)$ ) for the Alps.

The fact that post-eclogitic decompression occurs with no increase in temperature, but rather following a slightly retrogressive path (Fig. 11), suggests that uplift of the unit cannot be explained only by the effect of erosion, and that participation of some tectonic mechanism must be considered. The presence of a system of widespread extensional detachments in the Ordenes Complex suggests that this mechanism must be syncollisional (Arenas et al., 1995; Martínez Catalán et al., 1996; Fig. 12). The final part of the path is fairly close to isobaric cooling, also compatible with uplift models controlled by extensional tectonics (England and Thompson, 1984; England, 1987).

Some theoretical models developed for the tectonothermal evolution of accreted units in orogenic wedges are difficult to confirm from real tectonic and petrological data, especially those concerning subducted units. This is mainly caused because of the general overprinting of the high- $P$ mineral assemblages, which only allow their conservation in localized sectors, and also because of the complex evolution of orogenic wedges, whose extensional regime generates faults which usually cut the high- $P$ units, hindering in many cases the conservation of primary relationships. The tectonothermal evolution of the Agualada Unit in general confirms parts of the models of Davy and Gillet (1986) and Platt (1986, 1987)). Refrigeration by the underthrusting of colder units may play a major role in the geometry of the $P-T$ path and in the subsequent thermal evolution of thin units. Furthermore, the successive underthrust- 
ing and compensatory extension above seem to be able to maintain a moderate temperature in an accreted complex, helping to preserve high- $P$ assemblages.

\section{Acknowledgements}

We thank S. Sorensen for constructive correction of a preliminary version of the manuscript. Thanks are also due to G. Ernst and P. O'Brien for final reviews that helped us improve the quality of the paper. Electron microprobe analysis was conducted in the University of Montpellier II with the able assistance of Claude Merlet. This study was financed by grants PB91-0192-CO2 and PB94-1396-CO2 of the Spanish DGICYT. Barbara Knowles is kindly acknowledged for help in the English version.

\section{References}

Abati, J., 1994. Evolución tectonotennal de las eclogitas de la Unidad de Agualada (Complejo de Ordenes, NW del Macizo Ibérico). Tesis de Licenciatura, Univ. Complutense de Madrid, $182 \mathrm{pp}$.

Arenas, R., Gil Ibarguchi, J.I., González Lodeiro, F., Klein, E.. Martínez Catalán, J.R., Ortega Gironés, E., Pablo Maciá, J.G. de, Peinado, M., 1986. Tectonostratigraphic units in the complexes with mafic and related rocks of the northwest of the Iberian Massif. Hercynica II, 87-110.

Arenas, R., Martínez Catalán, J.R., 1993. High-pressure and high-temperature metabasites from the Sobrado Antiform (northwest of the Iberian Massif, Spain). A petrological and field study in a granulite-eclogite transition zone. Terra Nova Abstr. Suppl. 4, 1.

Arenas, R., Rubio Pascual, F.J., Díaz García, F., Martínez Catalán, J.R., 1995. High pressure microinclusions and development of an inverted metamorphic gradient in the Santiago Schists (Ordenes Complex, northwest Iberian Massif, Spain): Evidence of subduction and syncollisional decompression. J. Metamorph. Geol. 13, 141-164.

Austrheim, H., Griffin, W.L., 1985. Shear defornation and eclogite fornation within granulite-facies anorthosites of the Bergen Arcs, westem Norway. Chem. Geol. 50, 267-281.

Bohlen, S.R., Liotta, J.J., 1986. A barometer for gamet amphibolites and gamet granulites. J. Petrol. 27, 1025-1034.

van Calsteren, P.W.C., Boelrijk, N.A.I.M., Hebeda, E.H., Priem, H.N.A., Den Tex, E., Verdurnen, E.A.Th., Verschure, R.H., 1979. Isotopic dating of older elements (including the Cabo Ortegal mafic-ultramafic complex) in the Hercynian orogen of northwest Spain: Manifestations of a presumed Early Paleozoic mantle-plume. Chem. Geol. 24, 35-56.

Cawthorn, R.G., Collerson, K.D., 1974. The recalculation of pyroxene end-member parameters and the estimation of ferrous and ferric iron content from electron microprobe analyses. Am. Mineral. 59, 1203-1208.

Coleman, R.G., Lee, D.E., Beatty, L.B., Brannock, W.W., 1965. Eclogites and eclogites: Their differences and similarities. Geol. Soc. Am. Bull. 76, 483-508.

Chopin, C., 1984. Coesite and pure pyrope in high-grade pelitic blueschist of the westem Alps: A first record and some consequences. Contrib. Mineral. Petrol. 86, 107-118.

Dallmeyer, R.D., Gil Ibarguchi, J.I., 1990. Age of amphibolitic metamorphism in the ophiolitic unit of the Morais allochthon (Portugal): Implications for early Hercynian orogenesis in the Iberian Massif. J. Geol. Soc. London 147, 873-878.

Dallmeyer, R.D., Ribeiro, A., Marques, F., 1991. Polyphase Variscan emplacement of exotic terranes (Morais and Bragança Massifs) onto Iberian successions: Evidence from ${ }^{40} \mathrm{Ar} /{ }^{39} \mathrm{Ar}$ mineral ages. Lithos 27, 133-144.

Davy, P., Gillet, P., 1986. The stacking of thrust slices in collision zones and its thennal consequences. Tectonics 5, 913-929.

Díaz García, F., 1990. La geología del sector occidental del Comple jo de Ordenes (Cordillera Hercínica, NW de España). Nova Terra, Ediciones O Castro, 230 pp.

Ellis, D.J., Green, D.H., 1979. An experimental study of the effect of $\mathrm{Ca}$ upon gamet-clinopyroxene $\mathrm{Fe}-\mathrm{Mg}$ exchange equilibria. Contrib. Mineral. Petrol. 71, 13-22.

England, P.C., 1987. Diffuse continental defornation: Length scales, rates and metamorphic evolution. Philos. Trans. R. Soc. London A 321, 3-22.

England, P.C., Thompson, A.B., 1984. $P-T-t$ paths of regional metamorphism. Heat transfer during the evolution of regions of thickened continental crust. J. Petrol. 25, 895-928.

Emst, W.G., 1971. Metamorphic zonations on presumably subducted lithospheric slabs from Japan, California and the Alps. Contrib. Mineral. Petrol. 34, 43-59.

Essene, E.J., Fyfe, W.S., 1967. Omphacite in Califomian metamorphic rocks. Contrib. Mineral. Petrol. 15, 1-23.

Frost, B.R., Tracy, R.J., 1991. $P-T$ paths from zoned gamets: Some minimum criteria. Am. J. Sci. 291, 917-939.

García Garzón, L., de Pablo Maciá, J.G., de LLamas, J., 1981. Edades absolutas obtenidas mediante el método $\mathrm{Rb} / \mathrm{Sr}$ en dos cuerpos de ortogneises en Galicia occidental. Bol. Geol. Min. 92-94, 463-466.

Gil Ibarguchi, J.I., 1995. Petrology of jadeite-metagranite and associated orthogneiss from the Malpica-Tuy allochthon (northwest Spain). Eur. J. Mineral. 7, 403-415.

Gil Ibarguchi, J.I., Ortega Gironés, E., 1985. Petrology, structure and geotectonic implications of glaucophane bearing eclogites and related rocks from the Malpica-Tuy (MT) Unit, Galicia, northwest Spain. Chem. Geol. 50, 145-162.

Gil Ibarguchi, J.I., Arenas, R., 1990. Metamorphic evolution of the allochthonous complexes from the northwest of the Iberian Peninsula. In: Dallmeyer, R.D., Martínez García, E. (Eds.), Pre-Mesozoic Geology of Iberia. Springer Verlag, pp. 237246.

Graham, C.M., Powell, R., 1984. A gamet-hornblende geothermometer: Calibration, testing and application to the Pelona schist, southern Califomia. J. Metamorph. Geol. 2, 13-21. 
Holdaway, M.J., 1971. Stability of andalusite and the aluminium silicate phase diagram. Am. J. Sci. 271, 97-131.

Holland, T.J.B., 1980. The reaction albite $=$ jadeite + quartz determined experimentally in the range $600-1200^{\circ} \mathrm{C}$. Am. Mineral. $65,129-134$.

Holland, T.J.B., 1983. The experimental determination of activities in disordered and short range ordered jadeitic pyroxenes. Contrib. Mineral. Petrol. 82, 214-220.

Hollister, L.S., 1966. Garnet zoning: An interpretation based on the Rayleigh fractionation model. Science 154, 1647-1651.

Kohn, M.J., Spear, F.S., 1989. Empirical calibration of geobarometers for the assemblage gamet + hornblende + plagioclase + quartz. Am. Mineral. 74, 77-84.

Krogh, E.J., 1988. The gamet-clinopyroxene $\mathrm{Fe}-\mathrm{Mg}$ geothermometer: A reinterpretation of existing experimental data. Contrib. Mineral. Petrol. 99, 44-48.

Kushiro, I., 1962. Clinopyroxene solid solutions. Part 1. The $\mathrm{CaAl}_{2} \mathrm{SiO}_{6}$ component. Jpn. J. Geol. Geogr. 33, 213-220.

Lasnier, B., 1977. Découverte d'une série granulitique au coeur du Massif Central Français (Haut-Allier). Les terms basiques, ultrabasiques et carbonatés. Thesis, Univ. de Nantes, 351 pp.

Leake, B.E., 1978. Nomenclature of amphiboles. Am. Mineral. 63, 1025-1052.

Luth, W.D., Jahns, R.H., Tuttle, O.F., 1964. The granite system at pressures of 4 to 10 kbar. J. Geophys. Res. 69, 659-773.

Martínez Catalán, J.R., 1990. A noncylindrical model for the northwest Iberian allochthonous terranes and their equivalents in the Hercynian Belt of western Europe. Tectonophysics 179, 253-272.

Martínez Catalán, J.R., Klein, E., de Pablo Maciá, J.G., González Lodeiro, F., 1984. El Complejo de Ordenes: Subdivisión, descripción y discusión sobre su origen. Cuad. Lab. Xeol. Laxe 7, 139-210.

Martínez Catalán, J.R., Arenas, R., 1992. Deformación extensional de las unidades alóctonas superiores de la parte oriental del Complejo de Ordenes (Galicia). Geogaceta 11, 108-111.

Martínez Catalán, J.R., Arenas, R., Díaz García, F., Rubio Pascual, F.J., Abati, J., Marquínez, J., 1996. Variscan exhumation of a subducted Paleozoic continental margin: The basal units of the Ordenes Complex, Galicia, northwest Spain. Tectonics $15,106-121$.

Mattauer, M., 1983. Subduction de lithosphère continentale, décollement croûte-manteau et chevauchement d'echelle crustale dans la chaîne de collision himalayenne. C.R. Acad. Sci. Paris 269, 481-486.

Matte, P., Malusky, H., Caby, R., Nicolas, A., Kepezhinskas, P., Sobolev, S., 1993. Geodynamic model and ${ }^{39} \mathrm{Ar} /{ }^{40} \mathrm{Ar}$ dating for the generation and emplacement of the high pressure (HP) metamorphic rocks in southwest Urals. C.R. Acad. Sci. Paris 317 (II), 1667-1674.

Moecher, D.P., Essene, E.J., Anovitz, L.M., 1988. Calculations and application of clinopyroxene-garnet-plagioclase-quartz geobarometers. Contrib. Mineral. Petrol. 100, 92-106.

O'Brien, P.J., 1989. A study of retrogression in eclogites of the Oberpfalz forest, northeast Bavaria, West Germany, and their significance in the tectonic evolution of the Bohemian Massif.
In: Daly, J.S., Cliff, R.A., Yardley, B.W.D. (Eds.), Evolution of Metamorphic Belts. Geological Society Special Publication, 43, pp. 507-512.

Oxburgh, E.R., Turcotte, D.L., 1974. Thermal gradients and regional metamorphism in overthrust terrains with special reference to the eastern Alps. Schweiz. Mineral. Petrogr. Mitt. 54, 641-662.

Peacock, S.M., 1990. Numerical simulation of metamorphic pressure-temperature-time paths and fluid production in subducting slabs. Tectonics 9, 1197-1211.

Peacock, S.M., Rushmer, T., Thompson, A.B., 1994. Partial melting of subducting oceanic crust. Earth Planet. Sci. Lett. 121, 227-244.

Peucat, J.J., Bernard-Griffiths, J., Gil Ibarguchi, J.I., Dallmeyer, R.D., Menot, R.P., Cornichet, J., Iglesias Ponce de León, M., 1990. Geochemical and geochronological cross-section of the deep Variscan crust: The Cabo Ortegal high pressure nappe (northwestern Spain). Tectonophysics 177, 263-292.

Platt, J.P., 1986. Dynamics of orogenic wedges and the uplift of high-pressure metamorphic rocks. Geol. Soc. Am. Bull. 97, 1037-1053.

Platt, J.P., 1987. The uplift of high-pressure-low-temperature metamorphic rocks. Philos. Trans. R. Soc. London A 321, 87-102.

Powell, R., 1985. Regression diagnostics and robust regression in geothermometer/geobarometer calibration: The garnet clinopyroxene geothermometer revisited. J. Metamorph. Geol. 3, 231-243.

Råheim, A., Green, D.H., 1974. Experimental determination of the temperature and pressure dependence of the $\mathrm{Fe}-\mathrm{Mg}$ partition coefficient for coexisting garnet and clinopyroxene. Conuib. Mineral. Petrol. 48, 179-203.

Rast, N., 1965. Nucleation and growth of metamorphic minerals. In: Pitcher and Flinn (Eds.), Controls of Metamorphism. Oliver Boyds, Edinburgh, pp. 73-102.

Rossi, G., 1988. A review of the crystal chemistry of clinopyroxenes in eclogites and other high-pressure rocks. In: Smith, D.C. (Ed.), Eclogites and Eclogite Facies Rocks. Developments in Petrology, vol. 12, pp. 237-270.

Royden, L., Hodges, K.V., 1984. A technique for analyzing the thermal and uplift histories of eroding orogenic belts: A Norwegian example. J. Geophys. Res. 89, 7091-7106.

Rumble, D., 1973. Fe-Ti oxide minerals from regionally metamorphosed quartzites of western New Hampshire. Contrib. Mineral. Petrol. 42, 181-195.

Santos Zalduegui, J.F., Schärer, U., Gil Ibarguchi, J.I., 1995. Isotope constraints on the age and origin of magmatism and metamorphism in the Malpica-Tui allochthon, Galicia, northwest Spain. Chem. Geol. 121, 91-103.

Schäfer, H.J., Gebauer, D., Gil Ibarguchi, J.I., Peucat, J.J., 1993. Ion-microprobe $\mathrm{U}-\mathrm{Pb}$ zircon dating on the HP/HT Cabo Ortegal Complex (Galicia, northwest Spain): Preliminary results. Terra Nova Abstr. Suppl. 4, 22.

Spear, F.S., 1991. On the interpretation of peak metamorphic temperatures in light of garnet diffusion during cooling. J. Metamorph. Geol. 9, 379-388. 
Spear, F.S., Kimball, K.L., 1984. Recamp: A fortran program for estimating $\mathrm{Fe}^{3+}$ contents in amphiboles. Comput. Geosci. 10, 317-325.

Toksöz, M.N., Minear, J.W., Julian, B.R., 1971. Temperature field and geophysical effects of a down-going slab. J. Geophys. Res. 76, 1113-1138.

Tracy, R.J., 1982. Compositional zoning and inclusions in metamorphic minerals. In: Ferry, J.M. (Ed.), Characterization of Metamorphism Through Mineral Equilibria. Mineralogical Society of America, pp. 355-397.
Van der Wegen, G., 1978. Garnet-bearing metabasites from the blastomylonitic graben, western Galicia, Spain. Scr. Geol. 45, $1-95$.

Vogel, D.E., 1967. Petrology of an eclogite (and pyrigamite) bearing polymetamorphic rock complex at Cabo Ortegal, northwest Spain. Leidse Geol. Meded. 40, 121-213.

de Wit, M., Strong, D.F., 1975. Eclogite bearing amphibolites from the Appalachian Mobile Belt, northwestern Newfoundland: Dry versus wet metamorphism. J. Geol. 83, 609-627. 